\title{
IKT-ESZKÖZÖK HASZNÁLATÁNAK ÖSSZEFÜGGÉSE A KOGNITÍV MÜKÖDÉS ÁTALAKULÁSÁVAL ÉS SZEMÉLYISÉGTÉNYEZŐKKEL - ÁTTEKINTÉS NEMZETKÖZI EMPIRIKUS VIZSGÁLATOK EREDMÉNYEIRE ALAPOZVA
}

\author{
FARAGÓ BOGLÁRKA \\ Eszterházy Károly Egyetem, Pszichológia Intézet \\ E-mail: farago.boglarka@uni-eszterhazy.hu
}

Benyújtva. 2019. szeptember 4. - Elfogadva: 2020. január 27.

Célkitűzés: A tanulmány célja, hogy áttekintést nyújtson azon nemzetközi empirikus kutatások fóbb eredményeirôl, melyek azzal foglalkoznak, hogy az IKT-eszközök használata milyen összefüggést mutat a kognitív müködéssel, személyiségvonásokkal. A kognitív müködés területei közül a következókre fókuszál a tanulmány; gondolkodás, figyelem és emlékezet, végrehajtó funkciók, intelligencia. A személyiségvonások közül az impulzivitás, szenzoros élménykeresés és kontrollhelyelvárás szerepe jelenik meg.

Az áttekintés módszertana: Az összefoglaló tanulmány olyan kutatások eredményeire támaszkodik, melyek nemzetközi szintéren született empirikus vizsgálatok a fent felsorolt témákon belül. A tanulmány törekszik a témában friss, releváns nemzetközi empirikus kutatások áttekintésére. A fóbb eredmények és az ezekbôl levont következtetések: Az IKT-eszközök használata feltételezhetôen eredményez bizonyos átalakulásokat kognitív müködésünkben, azonban a kutatások eredményei arra a következtetésre vezetnek, hogy nem önmagában az IKT-használat az, ami a kognitív változásokat eredményezi, hanem az IKT-eszközök nem megfelelö használata. Vagyis valószinuuleg a megfelelō IKT-használati szokások elsajátítása a kulcs abban, hogy az IKT-eszközök kognitív müködésünkre gyakorolt negatív hatásainak mérséklésével ki tudjuk használni ezen eszközök elönyeit. Az IKT-eszközök nem megfelelô, problematikus használata olyan személyiségtényezókkel mutat összefüggést, mint az impulzivitás (türelmetlenség, alacsony önkontroll és kitartás), gátolatlanság, unalomintolerancia, külsố kontrollos kontrollhelyelvárás. Kérdéses azonban, hogy ezen személyiségbeli jellemzóket valóban az IKT-eszközök bizonyos típusú használata idézi-e eló, vagy fordítva; az eleve ilyen személyiségvonással jellemezhetô személyek hajlamosabbak a problematikus IKT-használatra? Ahhoz, hogy erre a kérdésre nagy bizonyossággal választ tudjunk adni, több randomizált kontrollált kutatásra van szükség a területen. A tanulmányban szerepló empirikus kutatásokat így kutatásmódszertani szempontból is fontos megvizsgálni annak érdekében, hogy árnyaltabb következtetéseket tudjunk megfogalmazni elemzésük révén.

Kulcsszavak: IKT-használat, kognitív müködés, személyiség, adaptív IKT-használat, randomizált kontrollált vizsgálatok 


\section{BEVEZETÉS}

Jelen áttekintố tanulmány célja azoknak a nemzetközi empirikus kutatási eredményeknek az áttekintése, amelyek azzal foglalkoznak, hogy modern infokommunikációs technológiai (IKT) eszközeink milyen kapcsolatban vannak kognitív múködésünk megváltozásával, valamint a különbözô személyiségtényezókkel. A következôkben elsôként a kognitív tényezókre gyakorolt hatásokat tekintjük át; így azokat a kutatásokat, amelyek az IKT-eszközök használatának a gondolkodással, figyelemmel, emlékezettel, végrehajtó funkciókkal, intelligenciával való összefüggéseit tárják fel, majd rátérünk az olyan személyiségbeli tényezókkel való kapcsolatokra, mint az impulzivitás, szenzoros élménykeresés és kontrollhelyelvárás. A tanulmány végén az empirikus kutatásokkal kapcsolatos problémákra is figyelmet fordítunk, így az okság feltárására alkalmas kutatási elrendezés szerepére, valamint ismét áttekintjük a tanulmányban megjelenô kutatásokat abból a szempontból, hogy milyen kutatási elrendezést alkalmaznak bennük, ami lehetôvé teszi az egyes vizsgálatokból levonható árnyaltabb következtetések megfogalmazását.

\section{AZ IKT-ESZKÖZÖK HASZNÁLATÁNAK ÖSSZEFÜGGÉSE A KOGNITÍV MUUKÖDÉS ÁTALAKULÁSÁVAL}

Megosztó kérdés a szakirodalomban, hogy kognitív múködésünk valóban átalakul-e a modern IKT-eszközök használatának következtében. Az optimisták szerint az új technológia pozitív változásokat eredményez gondolkodásmódunkban, ezzel szemben a peszszimisták felfogása, hogy ezek a technológiai eszközök az emberi természettôl idegenek (Pléh, 2011). Számos félelem lát napvilágot azzal kapcsolatban, milyen negatív hatásai vannak az IKT-eszközök alkalmazásának, onnan kezdve, hogy hosszú távú emlékezeti múködésünk elsorvad az új típusú külsô emlékezeti tárak megjelenése miatt, egészen társas kapcsolataink elsivárosodásáig. Egy harmadik nézôpont, a biológiai optimizmus képviselôi szerint ugyanakkor „kétségtelen, hogy az új technológiák megváltoztattak sok mindent, de ezek a változások úgy illeszkednek az ember meglévô neurobiológiai, evolvált rendszerébe, ahogyan például az írás is beilleszkedett” (Pléh, 2011, 13). A következôkben azt tekintjük át, hogy az empirikus kutatások eredményei szerint milyen átalakulások jelennek meg kognitív múködésünkben. Nem célja a tanulmánynak az IKT-eszközök használatával kapcsolatos félelmek erôsítése, sokkal inkább a változások tudatosítása, ami segíthet a hatékonyabb, adaptívabb IKT-használat elsajátításában.

Elsôként az IKT-eszközök használatának gondolkodásunk változásával kapcsolatos összefüggéseit vesszük sorra.

\section{Gondolkodásra gyakorolt hatások}

Kétfajta rendszert vagy folyamatot különíthetünk el a kognitív múködésben; az egyik a kevés kognitív forrást igénybe vevô intuitív, a másik a nagyobb erôfeszítést igényló analitikusabb rendszer (Kahneman, 2011). Barr és munkatársai (2015) azt vizsgálták, hogy a gyakori okostelefon-használat hatására elmozdul-e a hipotéziseknek megfele- 
lốen intuitívabb irányba a gondolkodásunk. A szerzók szerint a válasz igen; azonban az eredmény szempontjából az sem elhanyagolható, hogy mire használjuk gyakran okoseszközünket. Eredményeik szerint a szociális vagy szórakoztató jellegú alkalmazások gyakori használata nem mutat kapcsolatot a kognitív stílussal, szemben a keresốk gyakoribb használatával. Vagyis akikre jellemző, hogy azonnal rákeresnek a kívánt információra (ahelyett, hogy elmélyednének a kérdésben, saját gondolataikban keresnék rá a választ) akár okostelefonon, akár számítógépen, intuitívabb kognitív stílussal rendelkeznek.

Vagyis a modern világban az okostelefon, a számítógép és egyéb eszközök elménk kiterjesztései lehetnek. Mivel a humán kogníció olyan természetû, hogy ha lehetôség van rá, akkor a fent bemutatott két út - analitikus és intuitív - közül azt választja, amelyik kisebb erôfeszítést igényel, így gyakran elóforduló jelenség, hogy egy problémával szembesülve azonnal elérhetô IKT-eszközeinket használjuk ahelyett, hogy mi magunk gondolkodnánk el a lehetséges válaszokon, ennek pedig következményei lehetnek gondolkodási, problémamegoldási folyamataink múködésével kapcsolatban is (Barr és mtsai, 2015).

Egy kutatásban azt vizsgálták, milyen hatással van algoritmikus gondolkodásunkra, ha számológépet használunk fejben számolás helyett. A vizsgálati személyeknek egy viszonylag nehéz matematikai példát kellett megoldaniuk a három kísérleti csoport egyikében; az egyik csoportban fejben kellett számolni, a második csoportban papírt és ceruzát kaptak segítségül, míg a harmadikban számológép is rendelkezésre állt. A kutatók elemezték a résztvevôk problémamegoldási folyamatát, és arra jutottak, hogy az elsố (fejben számoló) csoportban a leggyakoribb stratégia a becslés. Ebben a csoportban a személyek igen hamar abbahagyják a problémamegoldást, a húsz fơbôl összesen heten dolgoztak öt percnél tovább a megoldáson. A papír-ceruza csoportban már több idôt töltöttek el a feladattal a személyek, és többen jutottak a helyes megoldás közelébe. Ezzel szemben a számológépes csoportban a személyek sok esetben kifejezetten könnyúnek titulálták a feladatot, mégsem volt teljesen egyöntetû a tökéletes megoldás (a húsz fóbôl tizenöt oldotta meg helyesen a feladatot), valamint elôfordult, hogy hezitáltak a válaszadás elôtt (hárman nem a megfelelô múveletet végezték el, és csak az eredményt látva jöttek rá a tévedésükre), a gondolkodás, ahogyan eljutottak a megoldáshoz, sok esetben nem volt egyértelmú. A kutatók szerint a múveletek végzésének egzakt útja nem látható a számológéppel számoló személyek számára, a problémamegoldás algoritmikus részét nem látják át, abban teljes egészében a gépre bízzák magukat. A szerzôk szerint ha hasonló szituációba kerülünk, rögtön a számológéphez fordulunk segítségért (a fejben számolók is sok esetben azt kértek a megoldáshoz segítségként), ami aritmetikus gondolkodási készségeinket sodorhatja veszélybe (Saljö, Eklund és Makitalo, 2006).

A technológiai eszközök kiterjesztett elmeként történô használatának tehát lehetnek bizonyos veszélyei gondolkodásunkra nézve, ugyanakkor azt is fontos megemlíteni, hogy ha megfelelôen használjuk azokat, azzal idôt és eróforrást spórolunk, melyet más tevékenységre fordíthatunk. A kulcs tehát a megfelelố használati szokások elsajátításában rejlik.

Sok kutatásban a multitasking hatását vizsgálják kognitív múködésünkre. Egy ilyen vizsgálatban azt nézték, hogy a média multitasking hatására információfeldolgozási 
stílusunk hogyan alakul. Ennek során vizsgálták a perceptuális és konceptuális feldolgozás változását. A perceptuális feldolgozás kétféle lehet; globális, amikor egy tárgy teljes képére fókuszálva dolgozzuk fel az információt, amelyet a tárgy hordoz; és lokális, vagyis amikor a tárgy részleteire fókuszálunk. Az eredmények szerint a média multitasking a lokális feldolgozás irányába mozdította el az információfeldolgozási stílust. A konceptuális feldolgozás lehet konkrét és absztrakt; utóbbi sokkal kidolgozottabb mentális reprezentációkat jelent, elôbbi egyszerúbb sémákkal jár együtt. Az eredmények szerint, ha a személyek konceptuális váltást igénylô helyzetben vesznek részt (vagyis két azonos típusú média között váltogatják a figyelmüket, ami ebben a vizsgálatban azt jelentette, hogy két képernyôn két különbözô animációs filmet kellett nyomon követniük), a személyek feldolgozási stílusa a konkrét irányba mozdul el (szemben azzal, amikor egymás után nézhették meg a két animációs filmet, vagy olyan szituációban, mely csak perceptuális váltást igényelt, vagyis a két képernyőn ugyanaz az animációs film jelent meg). Vagyis összességében elmondható, hogy a média multitasking szúkíti a figyelmi fókuszt, ezáltal konkrétabb információfeldolgozáshoz vezet (Kazakova, Cauberghe, Pandelaere és De Pelsmacker, 2015).

\section{Figyelemre, emlékezetre gyakorolt hatások}

Az infokommunikációs eszközök használata figyelmünkre is hatást gyakorol. Figyelmünk orientációs rendszerei közül az evolúciósan ôsibb külsố orientációra vannak nagy hatással modern eszközeink (Rothbart és Posner, 2015), melyek mindenféle érzékszervünkre hatva próbálják elvonni figyelmünket az elsôdleges feladatunkról (Wilmer és Chein, 2016). A végrehajtó figyelmi rendszer számára is nagy kihívást jelent a multimédia-környezet, melyben nagy erőfeszítést igényel a fókuszált figyelem fenntartása (Rothbart és Posner, 2015).

Egy 2014-es vizsgálat eredménye szerint a média multitasking nagyobb mértéke együttjárást mutat a mindennapi életben tapasztalt figyelmi hiányosságokkal, úgymint figyelmetlenség miatti tévesztések, spontán és szándékos elkalandozás és álmodozás, melynek oka, hogy a gyakran multitasking tevékenységet folytató személyek elterelhetôbbek, vagy optimális ingerszintjük eléréséhez több ingerre, nagyobb mentális stimulációra van szükségük, melyet az elkalandozással teremtenek meg. A vizsgálatban látens változó elemzést végeztek, melynek eredménye szerint a multitasking gyakorisága, valamint a spontán elkalandozás közötti kapcsolatot, illetve a multitaskinggyakoriság és a figyelmetlenségbôl fakadó hibák közötti összefüggést teljes egészében a figyelmi kihagyások közvetítik, vagyis valószínúleg a multitasking a belsô figyelmi kontroll csökkentésével vezet a mindennapi életben tapasztalható, figyelemmel összefüggó problémák megjelenéséhez (Ralph, Thomson, Cheyne és Smilek, 2014).

A figyelmi múködés emlékezetünkkel is szoros kapcsolatban van. A figyelem határozza meg, hogy mi kerül be a munkamemóriánkba, mennyire tudjuk megtartani az adott információt, mire tudunk visszaemlékezni, illetve mit raktározunk el a hosszú távú emlékezetben (Newell, 2015).

Emlékezeti múködésünk átalakul az infokommunikációs eszközök használatának hatására, ezzel kapcsolatban sok félelem látott napvilágot (pl. hosszú távú emléke- 
zeti képességünk elcsökevényesedésével kapcsolatban (Jackson, 2008), mások szerint ugyanakkor emlékezetünk adaptálódik a megváltozott feltételekhez. Ezt egy olyan kutatás eredményei támasztják alá, melyben Google-keresést modellezve azt találták, a személyek kevésbé emlékeznek arra az információra, melyrôl feltételezik, hogy késôbb is elérhetô lesz számukra, valamint nem magára az információra, hanem inkább annak elérhetôségére, helyére emlékszünk (Sparrow, Liu és Wegner, 2011). Vagyis igazodunk a megváltozott feltételekhez; a bárhol bármikor elérhetố információk világában nem feltétlenül az információ birtoklása válik értékké, fontosabb azt tudni, pontosan hol érhetem el a keresett információt.

A megváltozott világban egyre több információ, tananyag online vagy számítógépen érhetố el. Több kutatás foglalkozik azzal a kérdéssel, hogy a képernyốốl történô tanulás, gépi jegyzetelés hatására változik-e a tanultak felidézésének képessége. Egy vizsgálat eredményei szerint a felidézési teljesítményben meghatározó, hogy milyen formában olvassuk az írott szót; papírról vagy képernyôrôl. Utóbbi esetben sokszor nincsenek rögzített oldalak az olvasott dokumentumban, ami nehezíti a keresést, valamint az olvasottak felidézését, emellett híján van az olyan vizuális vagy taktilis formában szerzett információknak (pl. az információ helyének vizuális képe vagy a kézben tartott könyv tapintása), melyek jelentôs segítséget nyújthatnak az olvasottak felidézése során. Ennek következtében jobb felidézési teljesítménnyel jár együtt, ha ugyanazt az információt papírról olvassuk, mint ha képernyőrool (Mangen, Walgermo és Bronnick, 2012).

Sokan - fôként a felsôoktatási színtéren - már nem kézzel jegyzetelnek, hanem erre a célra is elektronikus eszközt - laptopot, olykor okostelefont - vesznek igénybe. Ha megvizsgáljuk az így készített jegyzetek minôségét, azok sokkal részletesebbek, hiszen laptopon gyorsabban tudunk jegyzetelni, mint kézzel, ugyanakkor ha arra vagyunk kíváncsiak, hogy mire emlékszünk a kétféle formátumú jegyzetelés esetén, egyértelmú a papírra történô jegyzetelés elônye Mueller és Oppenheimer (2014) vizsgálata szerint. Ennek magyarázata, hogy utóbbi esetben a jegyzetet készítô személy fel is dolgozza, megjegyzi a hallottakat amiatt, hogy nem tud mindent szó szerint leírni, így szükség van arra, hogy saját gondolkodására fordítsa le az elhangzottakat.

Nem támasztja alá ezt az eredményt ugyanakkor egy másik hasonló vizsgálat, melyben Sana, Weston és Cepeda (2013) azt találták, nincs különbség a papírra és gépen jegyzetelô csoport jegyzeteinek minôségében, és az utólagos felidézési teljesítményben sem. Az utóbbi eredményt megmagyarázhatja a jegyzetek minôségében mutatkozó különbség hiánya; vagyis elôfordulhat, hogy ebben a vizsgálatban a laptopon jegyzetelő személyek nem írtak le tökéletesen, szó szerint mindent, amit hallottak és láttak, így lehetséges, hogy jobban strukturált jegyzetek születtek laptopon is, ami kedvezett a leírtak megjegyzésének (egy és öt között pontozva a laptopon jegyzetelók jegyzetének átlagos minôsége 4,1, míg a kézzel jegyzetelôké 3,6 pontot kapott). Fontos megemlíteni, hogy a két jegyzeteléssel kapcsolatban említett vizsgálat ezen eredményei arra vonatkoznak, amikor a laptopot a személyek kizárólag jegyzetelésre használhatják, nem adott számukra a multitasking lehetôsége.

Utóbbi vizsgálatban azt is megnézték, hogy a laptopon multitasking viselkedést folytató diákok milyen teljesítményt mutatnak azokhoz képest, akiknél nem jelenik meg a többszörös feladatvégzés. Azt találták, hogy a multitasking viselkedés rontotta 
a jegyzetek minôségét, valamint az utólagos kikérdezés során nyújtott teljesítményt is. Emellett azoknak a résztvevóknek is csökkent a felidézési teljesítménye, akik, bár maguk nem multitaskingoltak, ugyanakkor a látóterükben ült valaki, aki igen. Ebben az esetben a teljes figyelmi fókusz hiánya hátráltatta a lejegyzetelt információ elaborációját és feldolgozását, ez vezetett a személyek felidézési teljesítményének csökkenéséhez (Sana és mtsai, 2013).

Sok kutatásban vizsgálják a munkamemória és a multitasking tevékenység közötti kapcsolatot. Ennek során a multitaskinggal kapcsolatban két dolgot vizsgálnak; a multitasking gyakorisága, illetve a multitasking hatékonysága. Azok az eredmények, melyek a multitasking tevékenység gyakorisága és a munkamemória-kapacitás közötti összefüggést vizsgálják, vegyes eredményeket mutatnak. Vannak olyan vizsgálatok, amelyekben kimutatható a ritkán multitaskingoló személyek előnye emlékezeti teljesítmény szempontjából a multitaskingot gyakran folytató személyekkel szemben. Egy olyan feladatban, melyben a személyeknek egy célingerben bekövetkezô változást kellett azonosítaniuk, a gyakran multitaskingolók több téves riasztást mutattak, vagyis kevésbé precíz reprezentációt alakítottak ki a munkamemóriájukban a célingerról a ritkán multitaskingolókhoz képest. Emellett elôbbiek nehézséget mutattak a célinger új ingertôl történố megkülönböztetésében, ami csökkent hosszú távú emlékezeti teljesítményre utal (Uncapher, Thieu és Wagner, 2016). Egy másik vizsgálat eredménye szintén ebbe az irányba mutat; a gyakori multitaskingot mutató személyek rosszabbul teljesítenek a munkamemória-feladat nehezedésével, valamint több téves riasztást mutatnak ebben a feladatban (a kutatásban a munkamemória mérésére az N-vissza tesztet alkalmazták). Az eredmények magyarázata, hogy a gyakran multitaskingolók számára nehezebb az irreleváns információ kiszúrése a munkamemóriából, ennek következtében több téves riasztást produkálnak (Ophir, Nass és Wagner, 2009).

Egy másik vizsgálatban ugyanakkor éppen az ellenkezójét találták, vagyis eredményeik szerint a számítógépet, csetet, internetet és videójátékokat is gyakrabban használó gyerekek, akikre jellemzóbb a feladatmegosztás, a munkamemória-feladatban is jobban teljesítenek. Mivel korrelációs jellegú vizsgálatról van szó, így nem egyértelmú az okság iránya; a magasabb munkamemória-kapacitású személyek eleve élvezetesebbnek találják a multitaskingot (mert számukra az könnyebb), így gyakrabban végzik, vagy fordítva; a gyakori multitasking tréning hatása következtében javul a munkamemória-kapacitás (Garcia, Nussbaum és Preiss, 2011).

Más kutatásokban egyáltalán nem találtak összefüggést a munkamemória-kapacitás és a multitasking gyakorisága között (Minear, Brasher, McCurdy, Lewis és Younggren, 2013), emellett a vizsgálati személyek által észlelt multitasking képesség sem mutatott kapcsolatot a munkamemória-teljesítménnyel (Sanbonmatsu, Strayer, Medeiros-Ward és Watson, 2013). Tehát az eredmények szerint a multitasking tevékenység gyakorisága nem feltétlenül van kapcsolatban a személy munkamemória-kapacitásával, vagyis nem szükségképpen azok a személyek végeznek gyakrabban multitasking tevékenységet, akik abban valóban jobbak.

Más vizsgálatokban a multitasking hatékonysága és a munkamemória-kapacitás közötti összefüggéseket tárták fel. Egy ilyen vizsgálatban a tanulás közbeni multitaskinghelyzetet modellezték; a személyeknek egy cikket kellett olvasniuk, és közben videót nézniük úgy, hogy mindkét tevékenységre figyelmet fordítanak. A magasabb munka- 
memória-kapacitással rendelkezô személyek az utólagos kikérdezés során több kérdésre tudtak helyesen válaszolni mind a cikkból, mind a videóból (Pollard és Courage, 2017). Redick és munkatársai (2016) eredményei szerint pedig a multitasking teljesítményben mutatkozó variancia legnagyobb részéért a munkamemória és a fluid intelligencia a felelôs, a multitasking teljesítmény és a munkamemória közötti kapcsolatban közvetítô tényezóként pedig a figyelmi kontroll és kapacitás mutatkozik meg (a látens változó elemzés eredményei alapján). Tehát feltételezhetô, hogy a multitasking tevékenység hatékonyságában szerepe van a munkamemóriának is.

\section{Végrehajtó müködésre gyakorolt hatások}

A multitasking próbára teszi végrehajtó funkcióink múködését is, úgymint a váltás képességét, a kognitív flexibilitást, vagyis az új feladat kívánalmaihoz való rugalmas alkalmazkodás képességét, a gátlási képességet, hiszen az egyik feladat végzése során le kell gátolni a másik feladathoz szükséges tényezőket (Loh és Kanai, 2015).

Egy, a multitasking gyakorisága és a gátló kontroll képességének a kapcsolatát vizsgáló kutatás eredményei szerint a multitasking gyakorisága alapján létrehozott három csoport (gyakran, ritkán és átlagosan) között nem volt különbség a gátló kontroll mérésére használt Flanker-tesztben megmutatkozó teljesítményben, ugyanakkor a Go/No-go feladatban jelentkezett különbség; az átlagos gyakoriságú multitasking tevékenységet folytató személyek teljesítménye alacsonyabb volt (több hibát vétettek, és alacsonyabb volt a reakcióidejük), mint a két szélsôséges csoporté abban az esetben, mikor a perceptuális teher magasabb volt. A magasabb perceptuális teher azt eredményezi, hogy a feladat végrehajtása nagyon sok kognitív forrást igényel, így kevesebb forrás marad az irreleváns információk azonosítására, vagyis ezek az irreleváns információk kevésbé befolyásolják a teljesítményt. A szerzók szerint két lehetôség emelkedik ki az eredmények magyarázatában. Az egyik, hogy a gyakran és ritkán multitaskingoló személyek jobb munkamemória-képességgel bírnak, mint az átlagos gyakorisággal multitaskingolók, így nagyobb terhelést jelentô helyzetben jobban teljesítenek. A másik, hogy a gyakran és ritkán multitaskingolók magasabb gátló kontrollal rendelkeznek, azonban más-más okból. A ritkán multitaskingolók magasabb gátló kontrollja a magasabb figyelmi fókuszuknak, a gyakran multitaskingolóknál feltételezhetôen a gyakori multitasking tréninghatásának köszönhetô (Murphy, McLauchlan és Lee, 2017).

Loh és Kanai (2015) feltételezése is segíthet megmagyarázni a fenti eredményt, mely szerint a gyakori multitaskinggal jellemezhetô személyek szélesebb figyelmi fókusza következtében azon feladatok megoldása jelent számukra problémát, amelyek alacsonyabb felülrôl lefelé irányuló kontrollt igényelnek, hiszen ebben az esetben az irreleváns információ könnyebben megragadja a szabad figyelmi kapacitásukat. Vagyis a fenti kutatásban azért nem jelentkezett a gátló kontroll feladatban a gyakran multitaskingoló személyek hátránya, mert az magas perceptuális teherrel járt együtt (ha ezt a feltételezést elfogadjuk, akkor azonban kérdésként merül fel, hogy alacsony teher esetén miért nem mutatkozott különbség a csoportok között Murphy és munkatársai vizsgálatában). 
Egy fMRI bevonásával végzett kutatás eredményei szerint megzavart figyelmi helyzetben (amikor a személyek két modalitásban kaptak mondatokat úgy, hogy csak az egyikre kellett odafigyelniük, és azokról eldönteniük, hogy szemantikailag helyesek-e) a gyakori multitaskinggal jellemezhetô személyek agyi aktivitása megnövekedett azokon az agyi területeken, amelyek szerepet játszanak a gátló kontrollban és a felülrôl lefelé irányuló kontrollban, vagyis megzavart helyzetben megnövekedett az arra irányuló erőfeszítése ezen személyeknek, hogy figyelmüket az elsôdleges feladaton tartsák. Osztott figyelmi helyzetben (ahol a személyeknek mindkét modalitásban érkezó mondatra oda kellett figyelniük) nem jelentkezett ilyen eltérés. Ez azt jelenti, hogy a gyakori multitasking valószínúleg nem a figyelemmegosztásban, feladatváltásban okoz nehézséget, hanem a zavaró irreleváns információ figyelmen kívül hagyásában (Moisala és mtsai, 2016). Ezt a feltételezést részben alátámasztja egy másik vizsgálat eredménye, melyben szintén azt találták, hogy a multitasking gyakorisága szerint létrehozott csoportok között nem volt különbség a feladatváltási képességben (CardosoLeite és mtsai, 2016).

Egy másik vizsgálatban szintén azt vizsgálták, hogy a gyakran multitaskingoló személyek miben mutatnak nehézséget az információfeldolgozásuk során. Az eredmények szerint a gyakran és ritkán multitaskingoló személyek teljesítményének pontosságában nem volt különbség a megzavart figyelmi helyzetben, ugyanakkor a reakcióidôben igen; a gyakori multitaskinggal jellemezhetô személyek reakcióideje ebben az esetben megnôtt. Így a szerzók szerint a gyakori többszörös feladatvégzés esetén a szelektív információfelvétellel van probléma, vagyis az irreleváns információ figyelmen kívül hagyásával, így az ilyen tevékenységet gyakran végzôket jobban befolyásolják a zavaró ingerek. Ennek oka, hogy valószínúleg a gyakori multitasking esetén a lentrôl felfelé irányuló figyelmi kontroll erôteljesebb, így zavaró tényezôk közepette nehezebb fókuszálniuk (Ophir és mtsai, 2009).

Egy 91 fớiskolás hallgatót vizsgáló magyar kutatásban multitasking környezetet modellezố helyzetben vizsgálták a résztvevôk teljesítményét, valamint a pihenésre szánt idô teljesítményre gyakorolt hatását. Elsôdleges tevékenységként egy igen hosszú, unalmas feladatot kellett végezniük a személyeknek. Emellett megjelentek olyan zavaró tényezók (pl. felugró ablakok), amelyek a való életbeli multitasking környezetben is elôfordulhatnak. A személyeknek lehetôségük volt arra, hogy elsôdleges feladatukat megszakítva feladatot váltsanak, pihenjenek (vagyis megnézzék, hogy a felugró ablakok milyen lehetôségeket kínálnak), majd visszatérhettek az elsôdleges feladathoz. Az eredmények szerint a pihenések hossza nem befolyásolta a Flanker-tesztben mutatott reakcióidốt, vagyis nem javította a feladat végzésének hatékonyságát, emellett minél hosszabb volt a pihenés, az annál inkább csökkentette az elsôdleges feladatban nyújtott teljesítményt, hiszen a pihenésre szánt idốt az elsôdleges feladattól vonták el a résztvevôk. Vagyis a sok pihenés hatását túlbecsülik a személyek, és alábecsülik az idôt, amit pihenéssel töltenek. Tehát a konklúzió szerint az elsôdleges feladat megszakítása pihenés céljából akkor nem jár teljesítményromlással, ha a rövid pihenôk után rövid idôn belül vissza tudunk térni elsôdleges feladatunk végzéséhez (Kvaszingerné Prantner, Soltész, Faragó, Pléh és Soltész-Várhelyi, 2016), ebben pedig fontos szerepe van a végrehajtó kontrollnak. 


\section{Intelligenciára gyakorolt hatások}

Intellektuális képességeink is változnak a modern technológia hatására. Az IQ-teszteken elért eredmény fokozatosan növekszik (Flynn, 1984), amit a technológia pozitív hatásával is magyarázhatunk, ugyanakkor ha más tesztek (például az egyetemi felvételiken alkalmazott vizsgálat verbális próbáinak) eredményét is megvizsgáljuk, melyben nem figyelhetô meg a pontszámok növekedése (szemben a verbális intelligenciatesztekkel), a következtetések árnyaltabbá válnak a technológia intelligenciára gyakorolt hatásával kapcsolatban (Greenfield, 2009).

Az intelligencia és a multitasking gyakoriságának kapcsolatát vizsgáló kutatások közül kiemelkednek Minear és munkatársai (2013) vizsgálatai. Elsố vizsgálatuk eredményei szerint a gyakori multitasking együttjárást mutat a magasabb impulzivitással, alacsonyabb önkontrollal, a gyakran multitaskingolók rosszabb teljesítményt nyújtanak a fluidintelligencia-teszten, nem különbözik ugyanakkor a két csoport (ritkán és gyakran multitaskingolók) a munkamemória-kapacitásban. A szerzók eredményüket azzal magyarázták, hogy a gyakran multitaskingoló személyek éppen az impulzivitásuk, türelmetlenségük miatt teljesítenek rosszabbul a fluidintelligencia-teszten (hiszen a nehezebb próbákat könnyebben feladják, mint kevésbé impulzív társaik).

Ezt a feltételezést sikerült alátámasztaniuk második vizsgálatukban, melyben azt találták, hogy az intelligenciateszt utolsó harmadában a ritkán multitaskingoló személyek reakcióideje nôtt meg, ami arra enged következtetni, hogy ôk jobban átgondolták az egyre nehezebb feladatokra adott válaszaikat, ennek köszönhetôen nagyobb pontosság jelent meg náluk a tesztben. Harmadik vizsgálatukban azt a kérdést is szerették volna feltárni, hogy valóban a türelmetlenség, magasabb impulzivitás vagy inkább a zavaró irreleváns információk figyelmen kívül hagyásának nehézsége az, ami a roszszabb intelligenciateszt-eredmény hátterében áll a gyakran multitaskingoló személyek esetében (hiszen az intelligenciateszt utolsó harmadában a zavaró irreleváns információk száma is megnô). Utóbbi tekintetében nem volt különbség a gyakran és kevésbé gyakran multitaskingoló személyek között (Minear és mtsai, 2013).

A három kutatásból az a következtetés vonható le, hogy valószínúleg a gyakran multitaskingoló személyek nem az alacsonyabb intellektuális képességeik, és nem is a zavaró, interferáló információk figyelmen kívül hagyásának nehézsége miatt teljesítenek rosszabbul a fluidintelligencia-teszten, mint a kevésbé gyakran multitaskingolók, hanem azért, mert impulzivitásuk magasabb, így türelmetlenebbek, ezért hamarabb feladják, a nehezebb próbákat már nem tudják megoldani (Minear és mtsai, 2013).

Egy, az emlékezetre gyakorolt hatásokkal kapcsolatban már említett kutatás eredményei szerint ahhoz, hogy valaki hatékony legyen a multitasking környezetben, fontos a megfeleló intellektuális képesség és munkamemória-kapacitás is (Redick, 2016). Nem támasztja ezt alá ugyanakkor az a vizsgálat, melyben látens változó elemzéssel nézték az osztálytermi hordozható IKT-eszközök használata és a tanulási teljesítmény közötti kapcsolatot, valamint az intellektuális képesség ezen kapcsolatban játszott szerepét. Eredményeik szerint a nem tanulási célú osztálytermi internethasználat és tanulási teljesítmény közötti negatív korreláció mértékét nem befolyásolta az intellektuális képesség, ami azt jelenti, hogy a magasabb intellektuális képességú tanulók sem képe- 
sek hatékonyabb multitasking tevékenységre (bár ebben a vizsgálatban az intellektuális teljesítményt nem intelligenciateszttel vizsgálták, hanem az ACT-pontszámot vették alapul, ami a felsôoktatásba történô belépéshez szükséges középiskolai teljesítmény felmérésére szolgáló méróeszköz) (Ravizza, Hambrick és Fenn, 2014).

\section{Az IKT-eszközök használatának összefüggése a kognitív müködés átalakulásával - Osszefoglalás}

A bemutatott kutatási eredményekbôl az a következtetés vonható le, hogy nem önmagában az IKT-használat az, ami a kognitív változásokat eredményezi, hanem az IKT-eszközök nem megfelelô használata. Gondolkodásunk intuitívabbá válik a túl gyakori keresômotor-használat következtében, problémamegoldó képességünk ezért gyengülhet. Alulról felfelé irányuló figyelmi rendszereinket könnyedén magukkal ragadják IKT-eszközeink, ugyanakkor a felülrôl lefelé irányuló, tudatos figyelmi múködés ellensúlyozhatja ezeket a negatív hatásokat. Emlékezetünk átalakul, multitasking helyzetben a megosztott figyelem miatt csökken az emlékezeti teljesítmény. Ez ugyanakkor munkamemória-kapacitásunktól is függ; a magasabb munkamemória-kapacitás hatékonyabb multitaskingot eredményezhet, munkamemóriánk pedig tréningezhetô. Az intellektuális képességekkel kapcsolatosan áttekintett vizsgálatok fontos tanulsága, hogy az adaptív IKT-használat hátterében nem az intellektuális teljesítmény áll (nem a rosszabb intellektuális képesség miatt teljesítenek rosszabbul a fluidintelligencia-teszten a gyakran multitaskingolók, és a magasabb intellektuális képességú tanulók sem képesek hatékonyabb multitaskingra). Vagyis valószínúleg a megfelelô IKT-használati szokások elsajátítása a kulcs abban, hogy az IKT-eszközök kognitív múködésünkre gyakorolt negatív hatásainak mérséklésével valóban ki tudjuk használni ezen eszközök elônyeit.

Egy magyar kutatásban az átlagos, alacsony és magas gyakoriságú IKT-használatot mutató csoportokat vizsgálva azt állapították meg, hogy az átlagos gyakoriságú használók azok, akik tendenciaszinten jobban teljesítenek bizonyos kognitív képességeket mérô teszteken is (a vizsgálati személyek életkora 10 és 18 év közötti volt) (Dávid, Dorner és mtsai, 2016). Vagyis kognitív múködésünk szempontjából - amellett, hogy hogyan használjuk - az is meghatározó, hogy milyen gyakorisággal használjuk IKT-eszközeinket. Sem a túl ritka, sem a túl gyakori használat nem feltétlenül elốnyös.

\section{AZ IKT-ESZKÖZÖK HASZNÁLATÁNAK ÖSSZEFÜGGÉSE SZEMÉLYISÉGBELI TÉNYEZŐKKEL}

A fentiekben bemutatott kutatásokból tehát kitûnik, hogy nem önmagában az IKT-használat, hanem a nem megfelelô IKT-használati szokások azok, amelyek problémákat okozhatnak teljesítményünkben, mindennapi múködésünkben. Kérdés, hogy meg lehet-e határozni olyan személyiségbeli tényezôket, amelyek ezeknek a nem megfelelô használati szokásoknak a hátterében állhatnak. A következókben olyan személyiségjellemzôk szerepét tekintjük át a problémás IKT-használattal összefüggésben, mint az impulzivitás, szenzoros élménykeresés és kontrollhelyelvárás. 


\section{Impulzivitás}

A gyakori multitasking több kutatás szerint is együttjárást mutat az impulzivitással; így például Uncapher és munkatársai (2016) a figyelmi impulzivitás és multitaskinggyakoriság között találtak pozitív kapcsolatot, míg Sanbonmatsu és munkatársai (2013) nemcsak a figyelmi, hanem a motoros impulzivitás és gyakori multitasking között is pozitív irányú összefüggést írtak le. A gyakori többszörös feladatvégzés hátterében ezeknél a személyeknél valószínúleg az áll, hogy a több feladat több jutalom lehetôségét rejti magában, ami az impulzív személyek számára fontos.

Az impulzivitás alskáláit vizsgálva leginkább a türelmetlenség és a kitartás hiánya az, ami összefüggést mutat a problémás IKT-használattal. Egy kutatásban azt vizsgálták, milyen mediáló szerepe van az impulzivitásnak a poszttraumás stressz zavar (PTSD) és problémás okostelefon-használat közötti kapcsolatban. Mind a kitartás hiánya, mind a türelmetlenség kapcsolatban volt a PTSD-tünetekkel és a problémás okostelefon-használattal az impulzivitás alskálái közül, a PTSD-tünetek és a problémás okostelefon-használat közötti kapcsolat mediálásában ugyanakkor csak a türelmetlenség játszott szerepet. A szerzôk magyarázata eredményükre, hogy az impulzív viselkedés gyakrabban jelenik meg intenzív distressz állapotában, hiszen az ilyen érzelmileg megterhelố helyzetek interferálnak a személyek önkontrollra való képességével. A szerzók szerint egy ilyen érzelmileg megterhelô helyzetben az okostelefon-használat azonnali jutalmazó hatást jelent, ami segít a negatív érzelmektôl idôlegesen eltávolodni (Contractor, Weiss, Tull és Elhai, 2017).

Egy másik kutatásban szintén a türelmetlenség és a kitartás hiánya mutatott kapcsolatot az impulzivitás alskálái közül a problémás mobiltelefon-használattal. A türelmetlenség fơként a veszélyes szituációban megjelenô mobilhasználattal mutatott összefüggést, mely magasabb distresszel jár együtt. Ezen eredmény magyarázata is megerôsíti a fentebb bemutatott kutatásból levonható következtetéseket, vagyis a szerzók szerint a türelmetlen személyeknek fơként intenzív emocionális kontextusban van problémájuk a mobilhasználatuk elhalasztásával, ugyanis az ilyen helyzetben a mobilhasználat jutalmazó volta miatt segít a negatív érzések csökkentésében (Billieux, Van der Linden és Rochat, 2008).

Olyan empirikus kutatások is vannak, melyekben azt vizsgálják, milyen jutalomforrások ösztönzik az IKT-használatot. Az egyik ilyen vizsgálatban a személyek válaszai alapján a tablethasználat hátterében álló jutalomforrásokat két csoportba sorolták. Az egyik csoport az instrumentális okokat foglalja magába; idetartozik a relaxáció a tablet segítségével, az információkeresés, a divat vagy státusz és a könnyebb munkaszervezés. A másik csoportba az intrinzik motivációk tartoznak, vagyis a bárhol/bármikor megvalósítható társas kapcsolódás, nagy képernyô, könnyú használat. Érdekes eredménye volt a kutatásnak, hogy az unalom nem jelent meg a tablethasználatra motiváló tényezôk között, tehát nem jellemzô a gyakoribb tablethasználat azoknál a személyeknél, akik szabadidejükben gyakran lassúnak érzik az idô múlását, vagy gyakran megtapasztalják a mentális és fizikai bevonódás teljes hiányát (Leung és Zhang, 2016).

Egy másik vizsgálatban azt kutatták interjúk elemzése alapján, hogy mennyire jellemzố kifejezetten a szociális médiára a jutalmazó hatás. Összesen tíz jutalomforrást gyújtöttek össze a személyek válaszai alapján, melyek a gyakori szociálismédia-hasz- 
nálat hátterében állnak. A vizsgálati személyek a leggyakrabban a szociális interakció igényét említették, összesen a válaszok $88 \%$-ában jelent meg ez a motívum. Ezt követi csökkenô gyakorisággal az információkeresés lehetôsége (a személyek 80\%-a említette), majd az idô eltöltése, fóleg unalom esetén (a személyek 76\%-a említette), illetve a személyek $64 \%$-ának válaszában jelent meg a szórakozás mint a szociális média használatát ösztönzô tényezô. A személyek válaszainak több mint felében a distressztôl való megszabadulás, realitástól való menekülés egyik eszközeként jelenik meg a szociális média (melyet összefoglalóan relaxációnak neveztek a szerzók, ezt a személyek 60\%-a említette) (Whiting és Williams, 2013). Vagyis mind a tablethasználat, mind az IKT-használaton belül a szociális média használatának hátterében fontos szerepet tölt be a stressztôl való megszabadulás, relaxáció az eszközzel, illetve alkalmazással.

Az önkontroll szoros kapcsolatban van az impulzivitással, az impulzivitás egyik alskálájaként is megjelenik. Így nem meglepô, hogy a magas önkontrollt mutató személyek kevesebb impulzuskontroll-problémával rendelkeznek, jobb a pszichológiai szabályozásuk, a mentális egészség összetevői jobban jellemzik óket, kevésbé jelennek meg náluk a különbözô pszichopatológiák (Tangney, Baumeister és Boone, 2004). Így az önkontroll magas szintje támogathatja a kontrollált, nem túlzó IKT-használatot is. Azonban az önkontroll túl magas szintje, a túlkontrollálás sem feltétlenül előnyös, könnyen vezethet például kényszeres vagy kompulzív viselkedéshez (Tangney és mtsai, 2004), mely szintén gyakori jelenség az IKT-használat kapcsán. Önszabályozásunk, kognitív kontrollunk szempontjából az internet világa folyamatos kihívást jelent - az információ azonnal elérhetô, a vágyak azonnal kielégíthetôk, azonnali jutalomforrásokhoz juthatunk általa. Az önkontroll rendkívül fontos a célvezérelt viselkedés fenntartásában olyan körülmények között, amikor az érzékszervi zavaró tényezôk (pl. okostelefon hangjelzése, felvillanása) vagy érzelmi zavaró tényezôk (pl. attól való szorongás, hogy lemaradunk valamirôl, amíg nem vagyunk online) száma magas. Modern IKT-eszközeink használata pedig bôvelkedik mind az érzékszervi, mind az érzelmi zavaró tényezókben (Wilmer és Chein, 2016). Így az önkontroll szerepét vizsgálják bizonyos IKT-vel összefüggố függóségek kapcsán is.

Egy kutatásban a Facebook közösségi oldallal kapcsolatos függôséggel összefüggésben vizsgálták az önkontroll szerepét. Az eredmények szerint a Facebook-függôséggel a kudarcorientált állapotorientáció mutatott kapcsolatot. Az ilyen orientációval rendelkezô személyekre jellemzô, hogy jobban bevonják ôket azok a gondolatok, melyek a kudarc lehetôségére vonatkoznak, inkább a negatív érzelmeikre fókuszálnak a célirányos tevékenység helyett, a negatív érzelmek, gondolatok szabályozásában pedig a leggyakoribb lehetôség, amelyet alkalmaznak, a menekülés - föként a közösségi oldalak világába - hangulatuk ideiglenes javítása érdekében. Emellett az önkontroll hiánya is kapcsolatot mutatott a Facebook-függôséggel (Błachnio és Przepiorka, 2016).

Egy nagy elemszámú, 10 és 22 év közötti tanulókat vizsgáló magyar kutatásban az önszabályozó tanulás sajátosságait vizsgálták az IKT-használattal összefüggésben. A vizsgálatban részt vevô tanulókat IKT-használatuk gyakorisága alapján három csoportba osztották; $25 \%$ alatt a keveset, $75 \%$ fölött a sokat használók, $25 \%$ és $75 \%$ között az átlagos gyakorisággal használók jelentek meg. A kutatás eredményei alátámasztották 
a szerzôk feltételezését, mely szerint az átlagos gyakoriságú IKT-használatot mutató tanulók magasabb önszabályozási képességgel rendelkeznek, mint a két szélsôséges csoportba tartozók (Dávid, Taskó és mtsai, 2016).

\section{Szenzoros élménykeresés}

Sok kutatásban az impulzivitás mellett a szenzoros élménykeresés szerepét is vizsgálják a problémás IKT-használattal, multitaskinggal összefüggésben. A multitasking gyakorisága így nemcsak az impulzivitással, de a szenzoros élménykereséssel is kapcsolatot mutat. Ennek oka feltételezhetôen az, hogy a többszörös feladatvégzés megadja az ilyen személyek számára szükséges magasabb stimulációt és kihívást (Sanbonmatsu és mtsai, 2013). A problémás IKT-használat szintén összefügg a szenzoros élménykereséssel, a veszélyes szituációban történô mobiltelefon-használat együtt jár a szenzoros élménykeresés magasabb szintjével, melynek hátterében valószínúleg az áll, hogy az ilyen helyzetek intenzív izgalommal járnak, mely a szenzoros élménykeresô személyek arousalszintjét a számukra optimálisra emeli (Billieux és mtsai, 2008).

A szenzoros élménykeresés alskálái közül a gátolatlanság és unalom intolerancia emelkednek ki a problémás IKT-használat hátterében. Rahmani és Lavasani (2011) vizsgálata szerint az internetfüggőnek definiálható személyek magasabb izgalom- és kalandkereséssel, magasabb gátolatlansággal és unalomra való hajlammal rendelkeztek, Lin és Tsai (2002) kutatásában pedig a szenzoros élménykeresés általában is összefüggést mutatott az internetfüggôséggel, azonban a szenzoros élménykeresés alskálái közül a gátolatlanság volt a legfontosabb elôrejelzôje annak.

Kérdés, hogy miért jelenik meg a gátolatlanság ilyen erôteljesen a problémás IKT-használat hátterében. Egy kutatásban azt vizsgálták meg, hogy mi jellemzó azokra a személyekre, akiknek a Facebook-használata problematikusnak nevezhetô. A vizsgálat szerint az ilyen személyek alacsonyabb interperszonális és emocionális képességgel bírnak a szemtôl szembeni kommunikációs helyzetekben, jellemzőjük a gyakoribb online énközlés és online kommunikáció kezdeményezése (Assunçao és Matos, 2017).

Egy másik vizsgálat szerint a szociális interakciós szorongás elômozdítja a kompulzív okostelefon-használatot, hiszen az ilyen egyének számára a telefonon történô kommunikáció, interakció csökkenti azt a diszkomfortérzetet, mely a társas kontaktusok következtében megjelenik náluk (Lee, Chang, Lin és Cheng, 2014). Nemcsak a szorongó, hanem a csupán félénkebb személyek is hajlamosabbak lehetnek a problémás IKT-használatra. Az ezzel foglalkozó kutatás eredménye szerint a félénkség mértéke együtt járt az internetfüggőség mértékének közepes mértékú, de statisztikailag szignifikáns növekedésével, valamint fontos elôrejelzője volt annak, hogy az ilyen személy gyakrabban használjon olyan alkalmazásokat, mint az e-mail vagy csetszoba (Chak és Leung, 2004). A való életben szociális gátlásokkal rendelkezô személyek számára az internet a gátak alóli felszabadulást jelentheti aszinkron formája és anonimitása következtében. A patológiás internethasználattal jellemezhetô személyek, akikre jellemzô a túlzott internethasználat, valamint az annak következtében megmutatkozó iskolai és interperszonális problémák, hangulatváltozások, nyitottabbnak és felszabadultabbnak mutatkoznak az interneten a gátlások alóli felszabadulás következtében (Niemz, Griffiths és Banyard, 2005). 
Vagyis összességében a gátolatlanság és a problémás IKT-használat közötti összefüggéssel kapcsolatban fontos kiemelni, hogy az internet világa - fôként a szociális jellegú online alkalmazások használata - segíthet a gátlások alóli felszabadulásban, ennek következtében könnyedén megjelenhet a problémás jellegú IKT-használat is.

Bár az impulzivitásnál említett, tablethasználatot ösztönzô tényezóket összegyưjtô kutatásban azt találták, az unalom érzése nem motiválja a tablethasználatot (Leung és Zhang, 2016), egy másik kutatás szerint az unalomra való hajlam összefüggést mutat a problémás internethasználattal, ugyanakkor nem jár együtt az interneten eltöltött több idôvel, ami azt jelenti, hogy ebben az esetben nem önmagában az internethasználat válik a probléma forrásává, hanem annak a természete (Skues, Williams, Oldmeadow és Wise, 2016). Egy másik vizsgálatban a szociális média használatának hátterében álló okok között megjelenik a szórakozás és az unalom, a vizsgálati személyek 57,3\%-a akkor használja a szociálismédia-felületet, ha unatkozik (Sponcil és Gitimu, 2012), valamint a fentebb már említett vizsgálatban, ahol a szociális média használatának hátterében álló jutalmazó tényezôket tárták fel, a harmadik leggyakoribb válasz volt, hogy azért használják a szociális médiát, mert unatkoznak, és szeretnék valamivel eltölteni az idôt (Whiting és Williams, 2013). A fenti kutatások eredményeinek ismeretében nem meglepô, hogy az unalomintolerancia kiemelkedik a szenzoros élménykeresés alskálái közül a nem megfelelő IKT-használattal összefüggésben.

\section{Kontrollhelyelvárás}

A kontrollhelyelvárás Julian B. Rotter elmélete alapján egy olyan kontinuum a személyiségben, melynek két végpontja a teljesen külsố és teljesen belsố kontrollos személyiség. A két végpont közötti különbség abban rejlik, hogy az adott személy hogyan észleli a megerôsítést. Ha a személy úgy gondolja, viselkedésének megerôsítése csak tôle függ, belsô kontrollos személyiségrôl beszélünk. Ezzel szemben az az elképzelés, hogy a saját viselkedés megerôsítése nem a személy erôfeszítésének, hanem más külsô erôknek a következménye, külsố kontrollos személyiségre utal (Rotter, 1966).

A kontrollhelyelvárás IKT-használattal való összefüggését több kutatásban is vizsgálták. Már 1990-ben is született ilyen vizsgálat, melynek eredményei szerint negatívabb számítógép iránti attitúdökkel mutat összefüggést a belsô kontrollos személyiség, emellett az ilyen személyek nagyobb valószínûséggel vesznek részt a számítógép használatát megtanító kurzusokon is. Ez utóbbi eredmény nem meglepố, hiszen a belsố kontrollos személyek mindent saját irányítás alá akarnak vonni, ezt pedig a számítógép-használattal kapcsolatban úgy érhetik el, ha megfeleló ismereteket szereznek róla. A negatív attitûd pedig azért alakul ki bennük a számítógépekkel kapcsolatban, mert azt gondolják, a saját erôfeszítéseiken múlik egyedül a megfelelô számítógépes készségek megszerzése (Woodrow, 1990).

Patricia Wallace (2002) Az internet pszichológiája címú könyvében olyan feltételezéssel él, hogy a belsô kontrollos személyek hajlamosabbak lehetnek az IKT-eszközök, az internet gyakori használatára, éppen azért, mert ez a terep remek lehetôséget nyújt számukra abban, hogy mindent saját irányítás alá vonjanak. Több kutatásban is vizsgálták ezt a feltételezést. Az egyik ilyen vizsgálatban az okostelefon-használattal összefüg- 
gésben tárták fel a kontrollhelyelvárás szerepét. Az eredmények szerint mind a külsô, mind a belsố kontrollos személyekre jellemzô volt a gyakori mobiltelefon-használat, de feltételezhetôen más-más okból. Ahogyan Wallace (2002) is feltételezte, a belsô kontrollos személyek valószínúleg ezt az eszközt is a saját kontroll szolgálatába állítják, ezért nố meg az eszköz használatának gyakorisága, a külsố kontrollos személyek ugyanakkor nem tudják megfelelốen korlátozni eszközhasználatukat. Abban azonban találtak különbséget a kutatók, hogy a külsô és belsố kontrollos személyek milyen módon használják okostelefonjukat. A belsô kontrollosok stratégiai módon használják ezt az eszközt, a külsô kontrollosokra ugyanakkor jellemzôbb a nem megfelelô helyen vagy időben történô okostelefon-használat (Li, Lepp és Barkley, 2015).

Egy másik kutatásban a kompulzív okostelefon-használat összefüggését vizsgálták a kontrollhelyelvárással, más tényezốk mellett. Kompulzív médiahasználatnak nevezzük, ha a személy állandó késztetést érez médiaeszközei ellenôrzésére, hiszen ez a viselkedés azonnali jutalmat jelent számára. Eredményeik szerint a kompulzív okostelefon-használat jellemzóbb a külsố kontrollos személyekre, a passzivitás irányába mutató tendenciájuk és az alacsonyabb önkontrollszintjük miatt (Lee és mtsai, 2014).

A külsố kontrollos kontrollhelyelvárás az online játékok iránti könnyebb elcsábulásban is szerepet játszik. Egy ezzel foglalkozó vizsgálat eredményei szerint a személyek azon szándékát, hogy a jövôben is játszanak online játékokkal, három tényezô befolyásolja; maga a játék élvezete, az elcsábulás és a szociális affiliációs szükségletek. A kontrollhelyelvárásnak módosító szerepe volt abban, hogy ezek a tényezók milyen hatást gyakorolnak a személy játékra irányuló szándékára. A belsô kontrollosok összességében alacsonyabb hajlandóságot mutattak az online játékok játszására, óket kevésbé befolyásolta az elcsábulás, az affiliációs szükséglet és a koncentráció hiánya (Koo, 2009).

\section{Az IKT-eszközök használatának összefüggése a személyiségbeli tényezókkel - Összefoglalás}

A feldolgozott kutatási eredmények alapján megállapítható, hogy az IKT-eszközök nem megfelelô, problémás, esetleg kényszeres jellegú, addiktív használata kapcsolatban van az olyan személyiségjellemzókkel, mint a türelmetlenség, az önkontroll hiánya, a gátolatlanság, az unalomintolerancia, a külsô kontrollos kontrollhelyelvárás. A szenzoros élménykeresés stabilabb személyiségvonásnak tekinthetô (Mayer, Lukács és Pauler, 2012), az impulzivitás azonban változtatható, „nem olyasmi, amitôl soha életében nem szabadulhat az ember" (Goleman, 2015, 212), kontrollhelyelvárásunk pedig egy tanult tulajdonság, ezáltal annak változtatása megvalósítható, tanulással módosítható (Kormanik és Rocco, 2009). Mindezen tényezôk alakítása, tudatos formálása lehetséges, hogy IKT-használatunkat is tudatosabb irányba mozdítja el. Kérdés ugyanakkor, hogy milyen irányú okságról beszélünk? Vajon nem megfelelô IKT-használatunk az, amely impulzívabbá, gátolatlanabbá, külsố kontrollosabbá tesz, vagy eleve ezen személyiségvonások megléte hajlamosít bizonyos típusú IKT-használatra? Az ezzel kapcsolatos kutatások sok esetben nem tudnak megfelelố választ adni erre a kérdésre. Így fontos arról is szót ejteni, milyen korlátai vannak a fentiekben bemutatott vizsgálatokban alkalmazott kutatási elrendezéseknek. 


\section{AZ EREDMÉNYEK ÉRTELMEZÉSÉNEK KORLÁTAI - A KORRELÁCIÓS JELLEGÛ́ VIZSGÁLATOK HÁTRÁNYA}

Az IKT-eszközök hatásával foglalkozó kutatások sok esetben korrelációs jellegúek, ami azt jelenti, hogy ezen vizsgálatokból nem egyértelmú az okság iránya; vagyis, hogy a kutatások által feltárt kognitív vagy személyiségbeli jellemzôk a technológiahasználat következtében jelennek meg, vagy ellenkezôleg; a feltárt kognitív és személyiségbeli jellemzókkel bíró személyek hajlamosabbak bizonyos típusú IKT-használatra.

Simons és munkatársai (2016) a különbözô kognitív tréningek hatékonyságát vizsgálták több kutatás eredményeit áttekintve tanulmányukban, mely során kitértek arra is, hogy az ezekben a vizsgálatokban alkalmazott kutatási elrendezéseknek milyen hátrányai vannak. Tanulmányukban bírálják a korrelációs módszert, mely nem teszi lehetôvé az okság irányának megállapítását. A longitudinális módszer egy jobb alternatíva, ugyanakkor az azzal kapcsolatban felmerüló probléma, hogy rendkívül megnehezíti a vizsgált tényezóktôl eltérô összetevôk hatásának kontrollját. A szerzók szerint a legjobb módszer, amellyel az okság iránya is egyértelmúen megállapíthatóvá válik, a kísérleti elrendezés alkalmazása, bizonyos feltételek mellett. Így nagyon fontos a megfeleló kontrollcsoport alkalmazása, akiket illesszünk a kísérleti csoporthoz, fontos, hogy a kontrollcsoport tagjai a kísérleti csoporttól csak egyetlen - az általunk vizsgálni kívánt - jellemzóben térjenek el, a vizsgálati személyek random módon kerüljenek a kísérleti és kontrollcsoportba, és használjunk kettôs vak elrendezést.

Wilmer, Sherman és Chein (2017) irodalmi áttekintô tanulmányukban az okostelefon használata és a kognitív és affektív múködés közötti összefüggésekre fókuszálnak. Ennek során felvázolják az ezen a területen végzett kutatások nehézségeit is. Ezek között elsố helyen szerepel a megfelelô kísérleti elrendezés kialakításának problémája, hiszen az okostelefon (de más IKT-eszköz is) olyannyira elterjedt, hogy szinte lehetetlen a vizsgálati személyeket random módon besorolni különbözó technológiai hozzáféréssel jellemezhetô csoportokba. A szerzôk szerint még ha találnánk is olyan vizsgálati személyeket, akik egyáltalán nem rendelkeznek az adott technológiai eszközzel (esetükben okostelefonnal), nem használják azt, szintén nagyon nehézkes olyan kísérleti csoport összeállítása, akik tapasztalt technológiahasználók, ugyanakkor minden másban (pl. szocioökonómiai státusz, életkor stb.) megegyeznek a kontrollcsoportba tartozó, technológiahasználat szempontjából naiv személyekkel. Így a legtöbb kutatás ezen a téren kvázi-kísérleti elrendezést vagy korrelációs jellegú vizsgálatot alkalmaz, mely az okság megállapítására nem alkalmas. Megemlítik továbbá az önbevallásos kérdôívek használatának problémáját is, melyek gyakran nem megbízhatók, különösen az IKT-használat felmérésében tapasztalható, hogy az önbevallásos kérdôívben megjelenô eredmények nem felelnek meg a valóságnak.

Így a jelen tanulmányban is megjelent empirikus kutatások eredményeit is ezen korlátok figyelembevételével érdemes megfontolni. A következô táblázat összefoglalóan mutatja, hogy a tanulmányban említett vizsgálatokban milyen kutatási elrendezést alkalmaztak.

A táblázatból látható, hogy a jelen tanulmányban áttekintett vizsgálatok legnagyobb része korrelációs jellegú, kevés az olyan kutatás, amely randomizált kontrollált kísérleti elrendezést alkalmazna. Így fontos feladat a további kutatások megtervezésekor arra fókuszálni, hogy minél több olyan legyen, mely az okság irányáról is megbízható információt szolgáltat. 


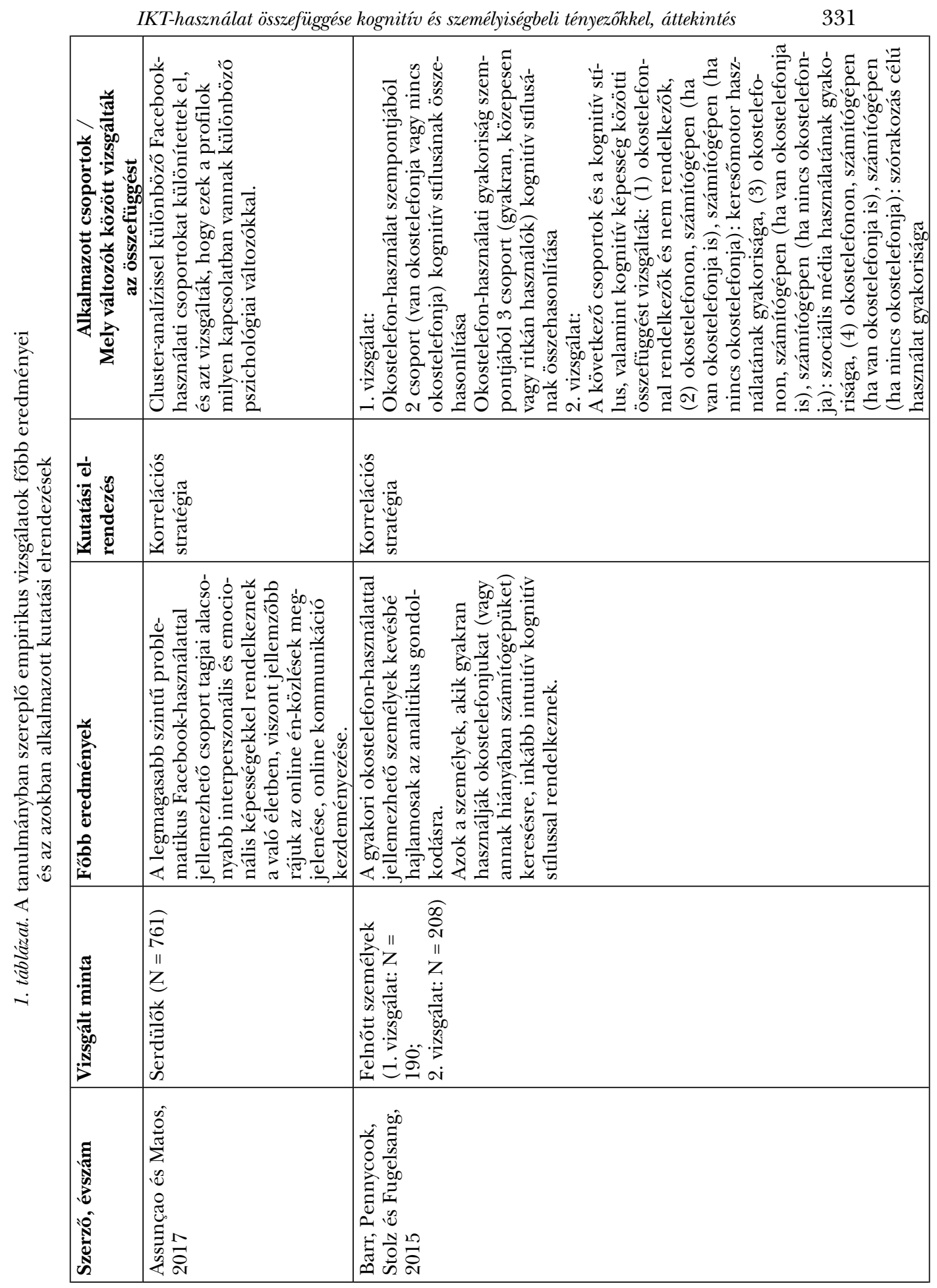




\begin{tabular}{|c|c|c|c|c|}
\hline 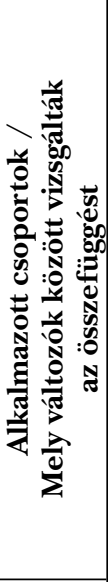 & 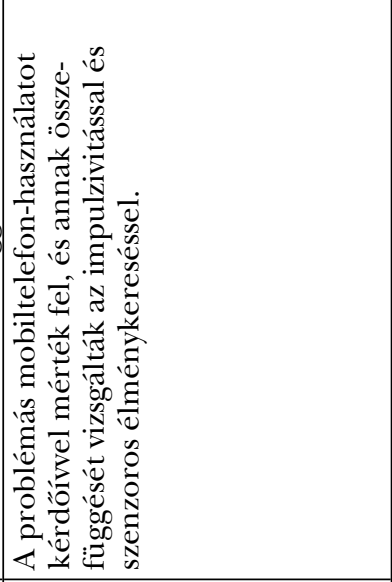 & 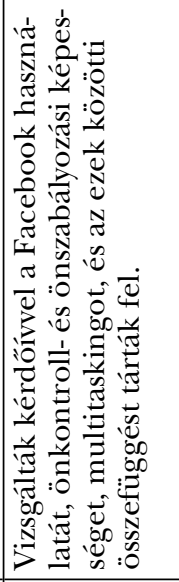 & 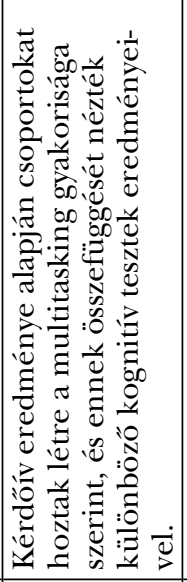 & 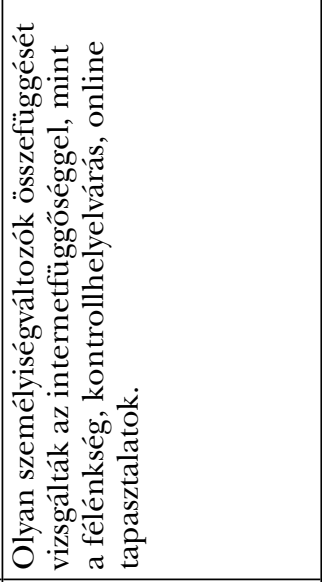 \\
\hline 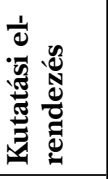 & 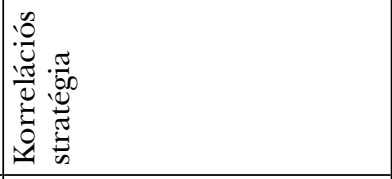 & 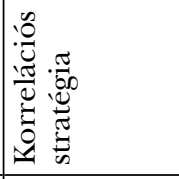 & 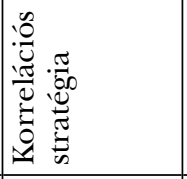 & 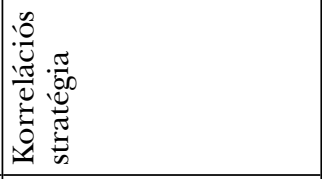 \\
\hline 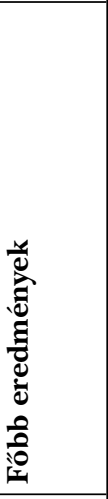 & 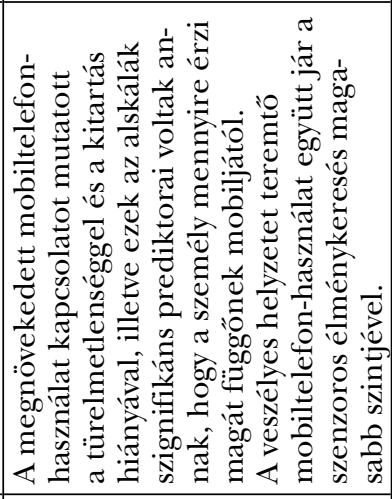 & 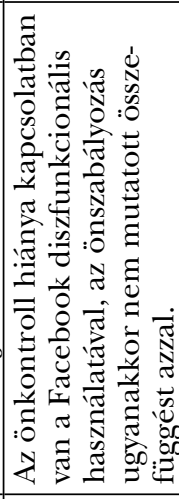 & 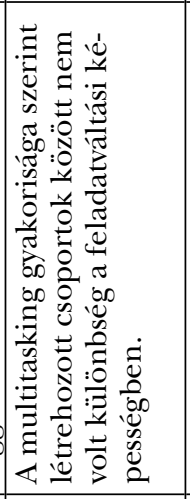 & 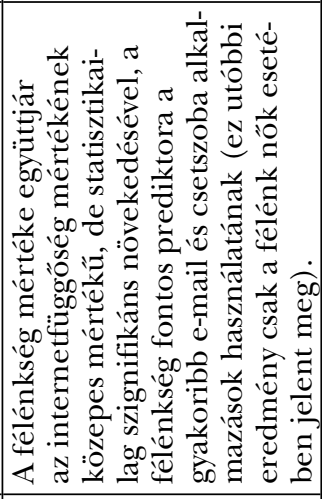 \\
\hline 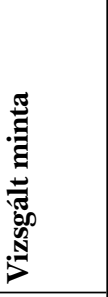 & 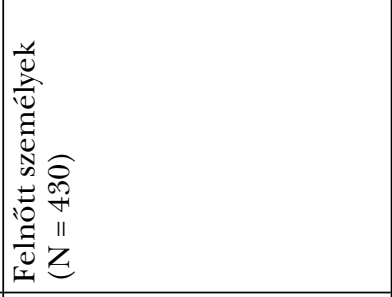 & 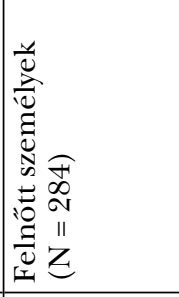 & 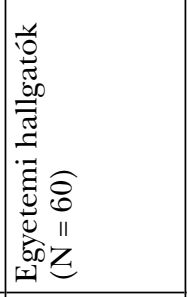 & 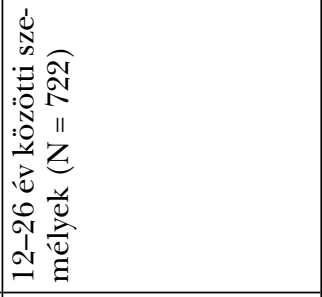 \\
\hline 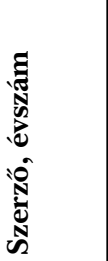 & 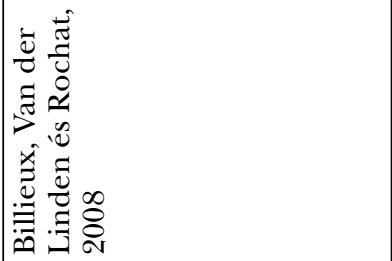 & 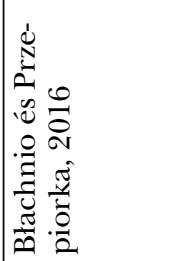 & 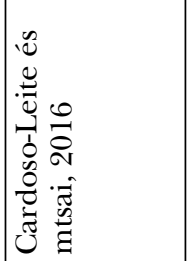 & 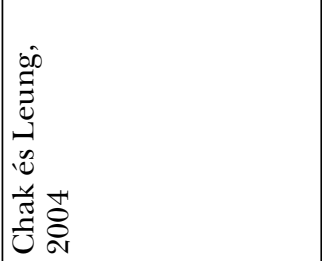 \\
\hline
\end{tabular}




\begin{tabular}{|c|c|c|c|c|}
\hline 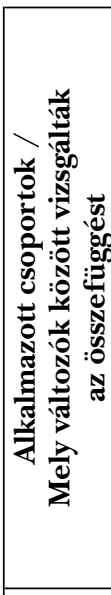 & 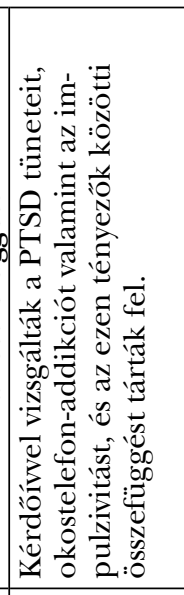 & 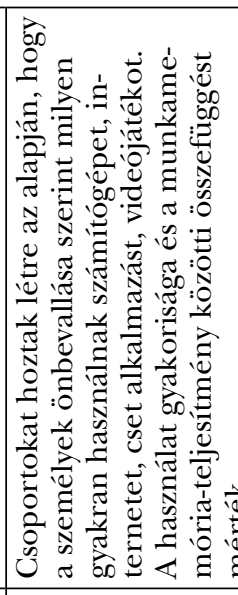 & 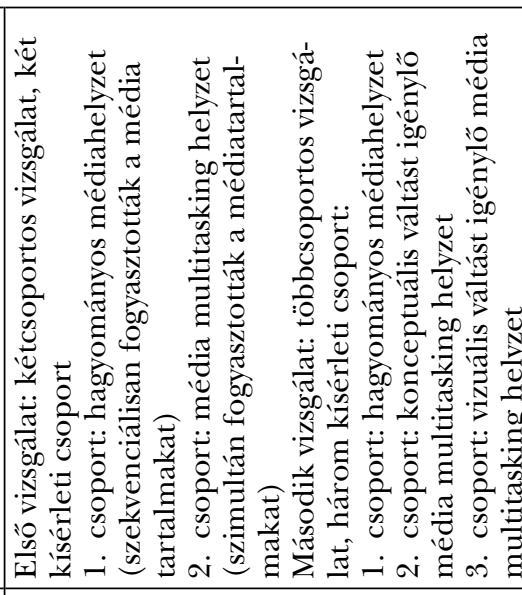 & 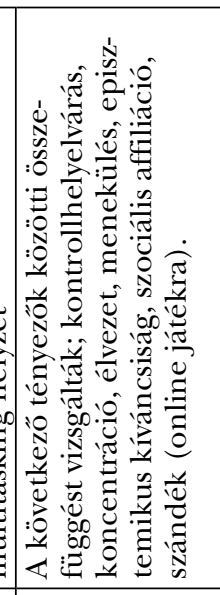 \\
\hline 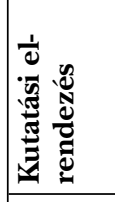 & 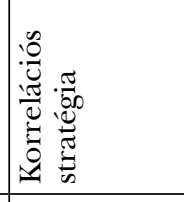 & 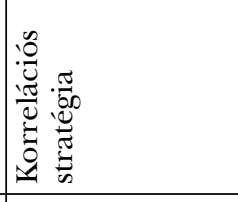 & 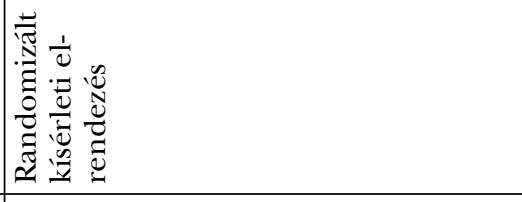 & 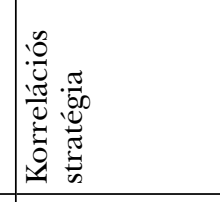 \\
\hline 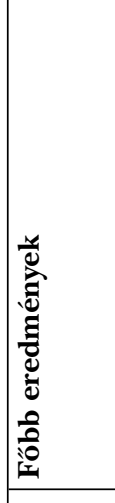 & 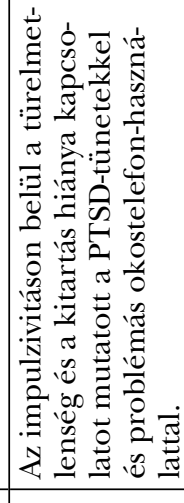 & 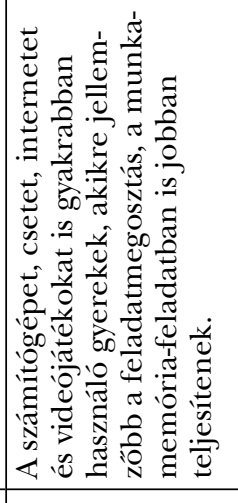 & 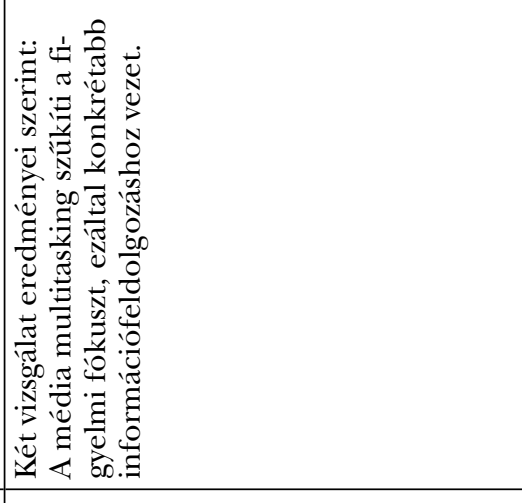 & 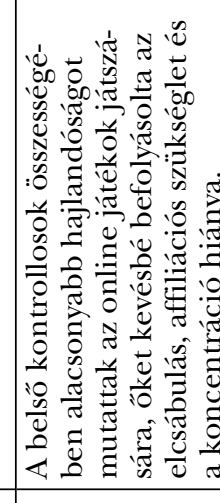 \\
\hline 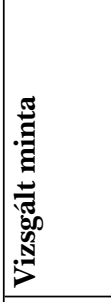 & 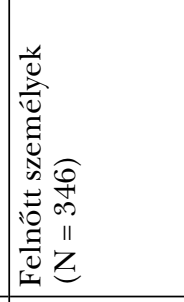 & 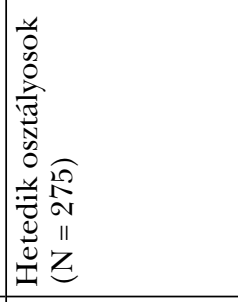 & 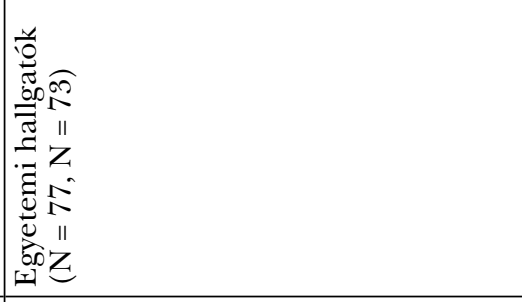 & 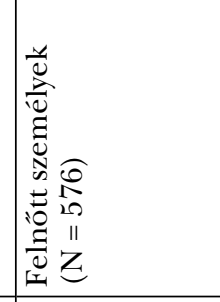 \\
\hline $\mid$ & 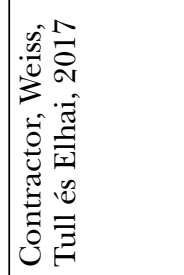 & 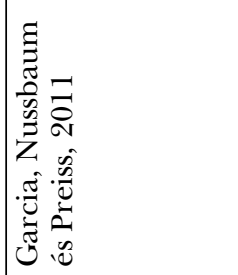 & 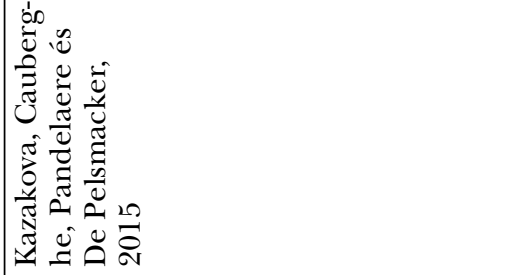 & 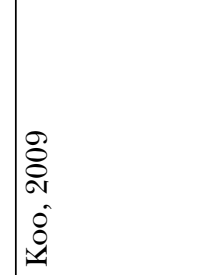 \\
\hline
\end{tabular}




\begin{tabular}{|c|c|c|c|}
\hline 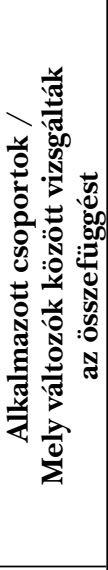 & 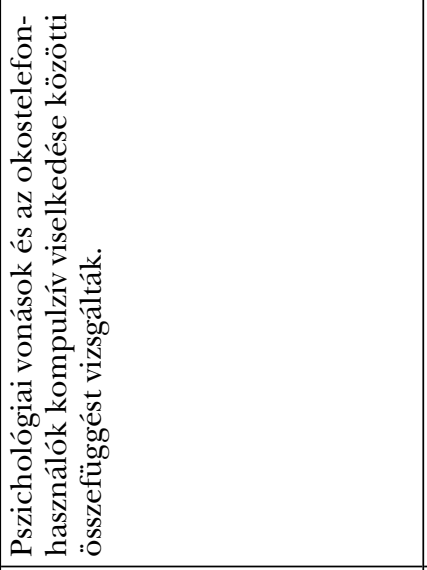 & 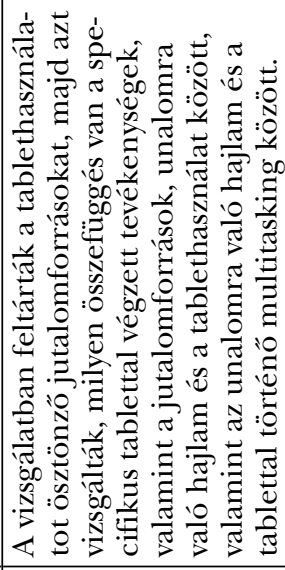 & 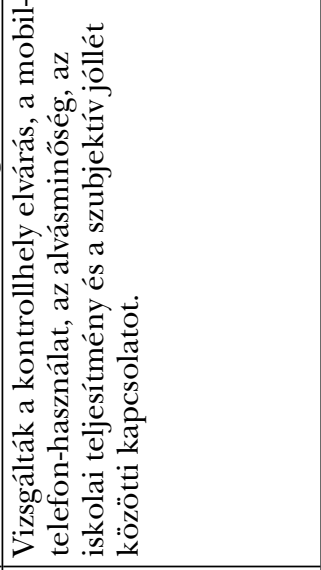 \\
\hline 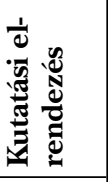 & 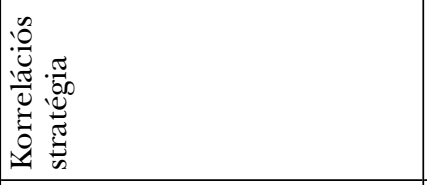 & 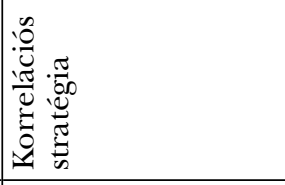 & 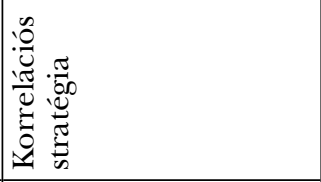 \\
\hline 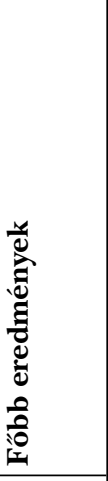 & 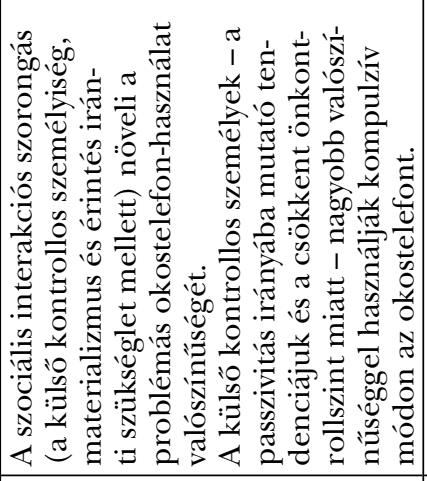 & 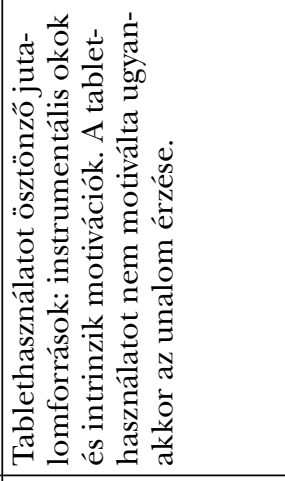 & 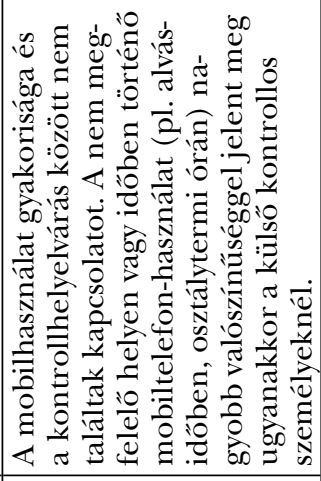 \\
\hline 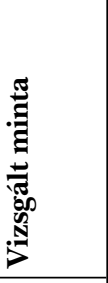 & 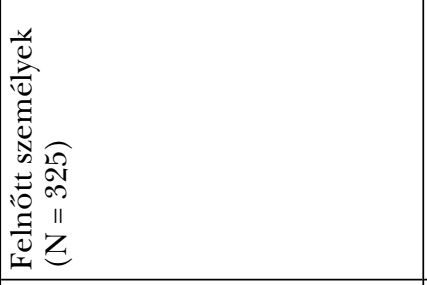 & 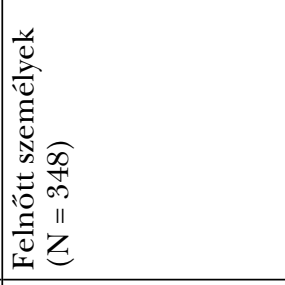 & 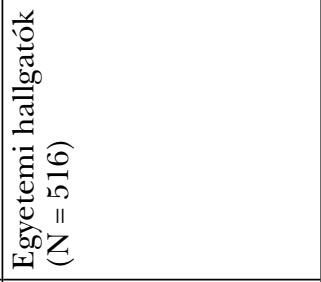 \\
\hline 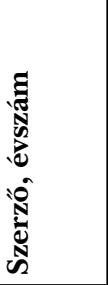 & 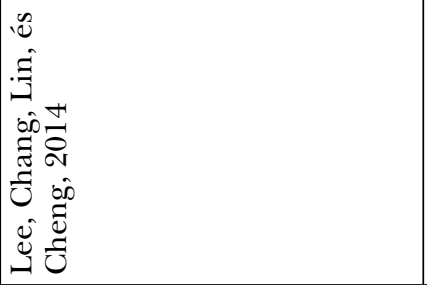 & 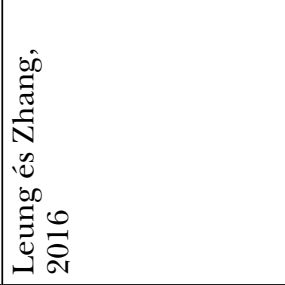 & 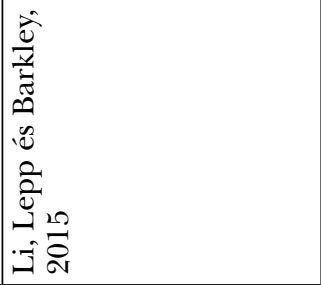 \\
\hline
\end{tabular}




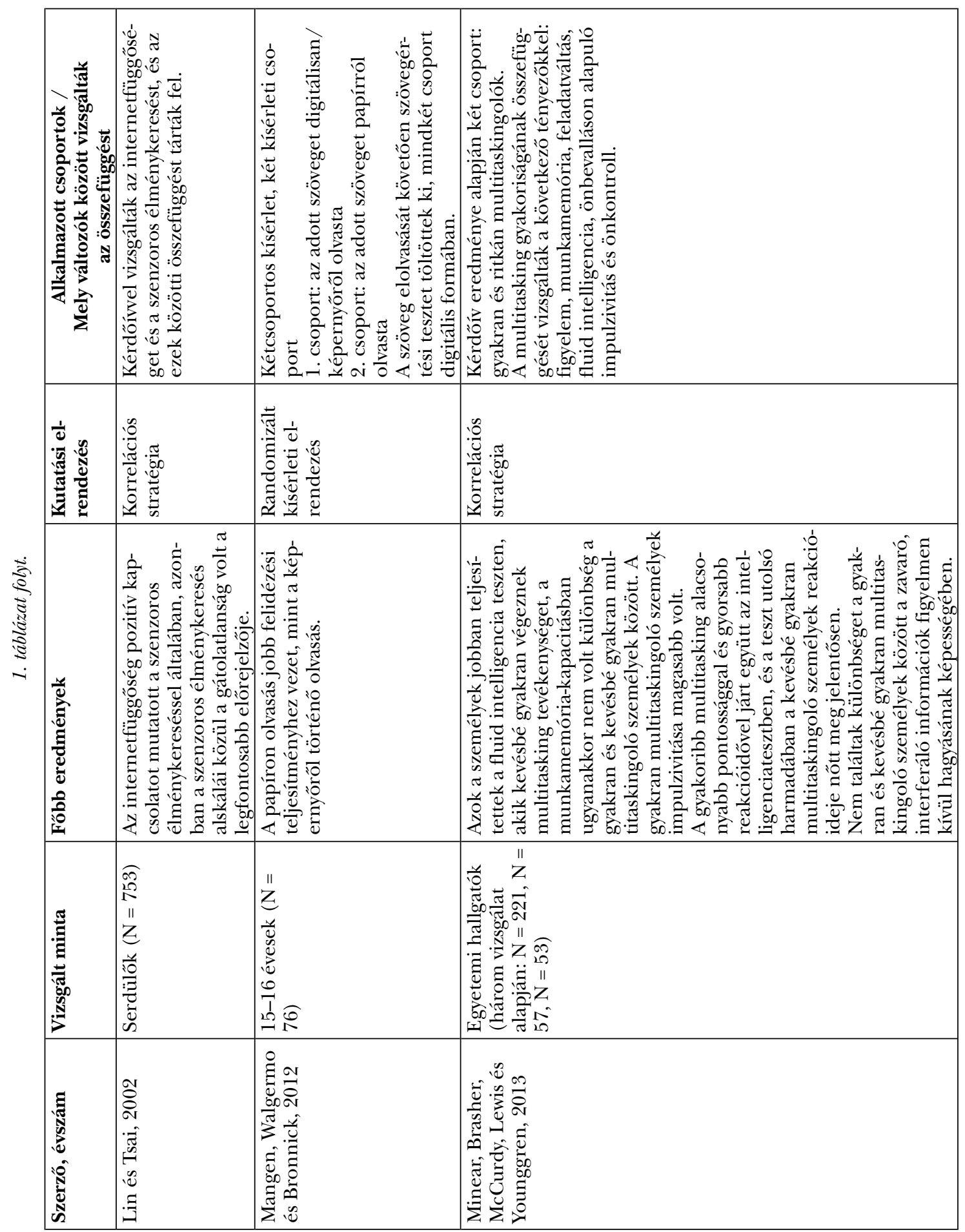




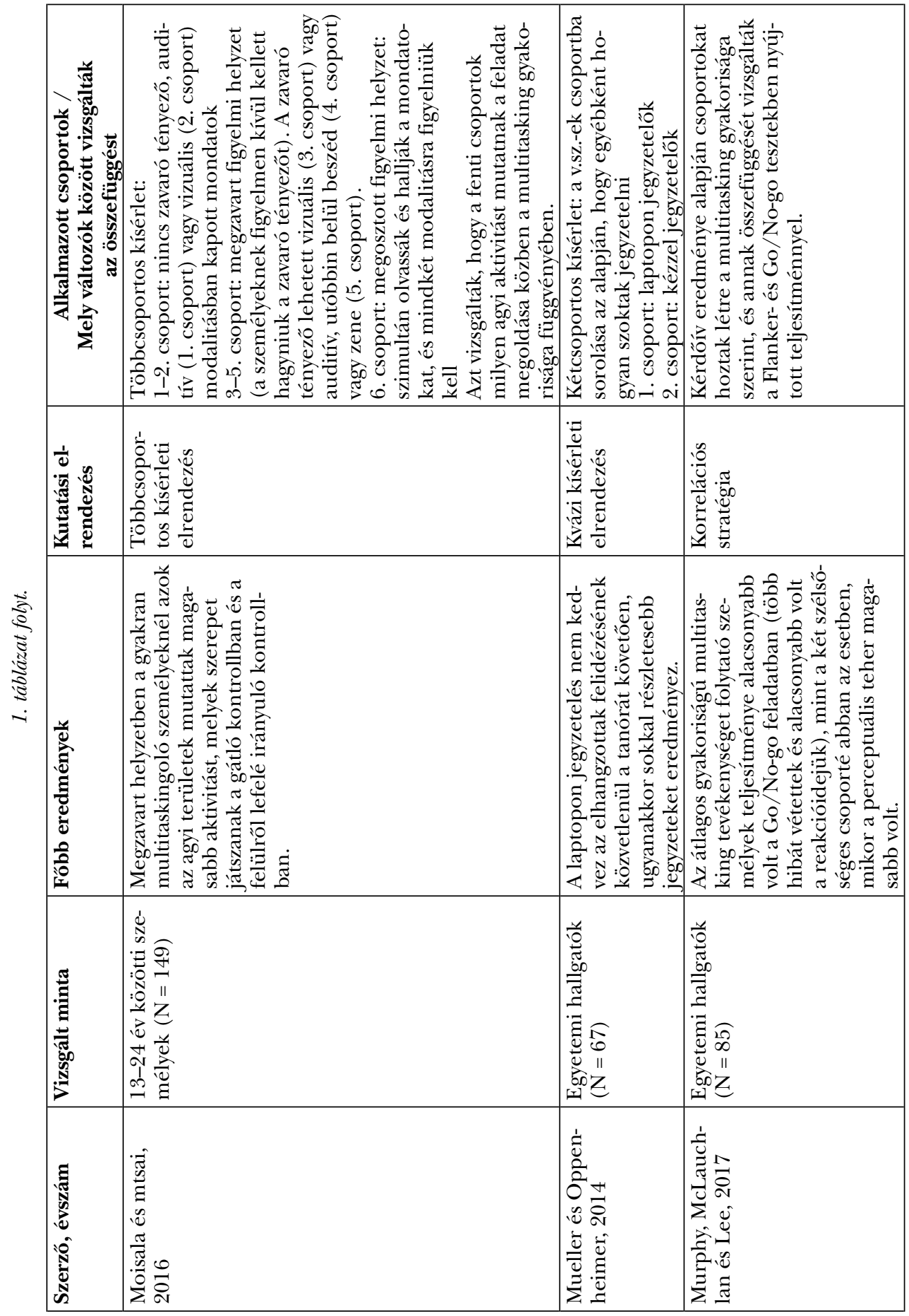




\begin{tabular}{|c|c|c|c|}
\hline 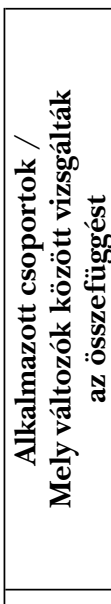 & 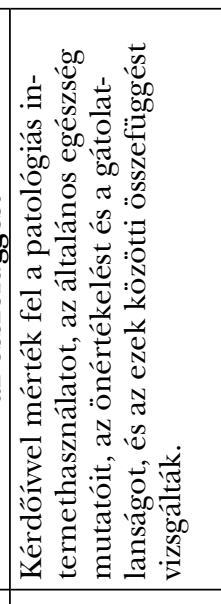 & 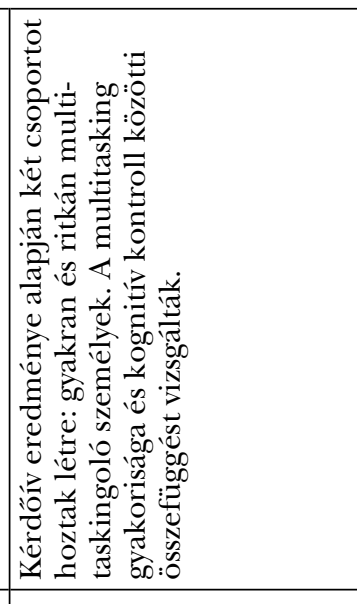 & 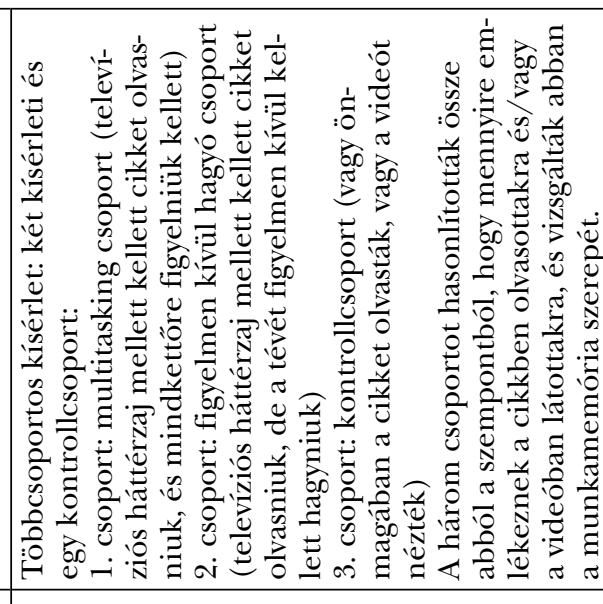 \\
\hline 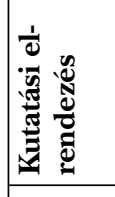 & 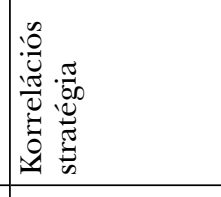 & 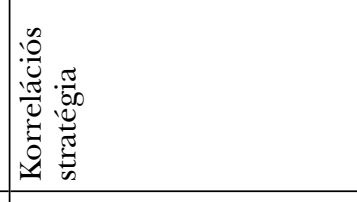 & 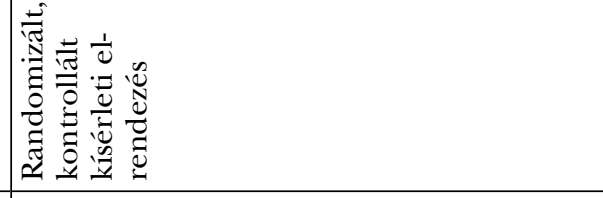 \\
\hline 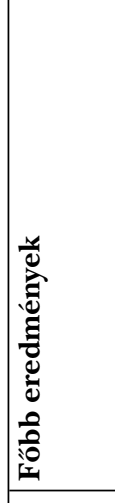 & 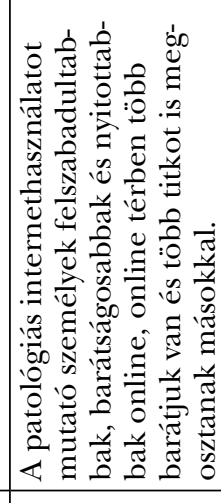 & 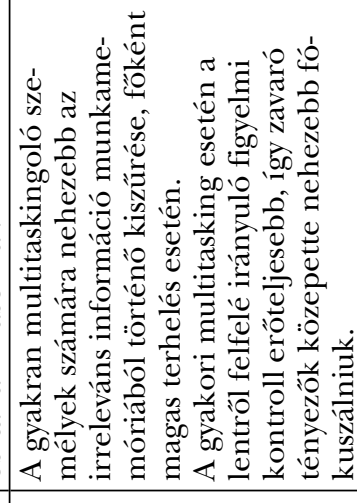 & 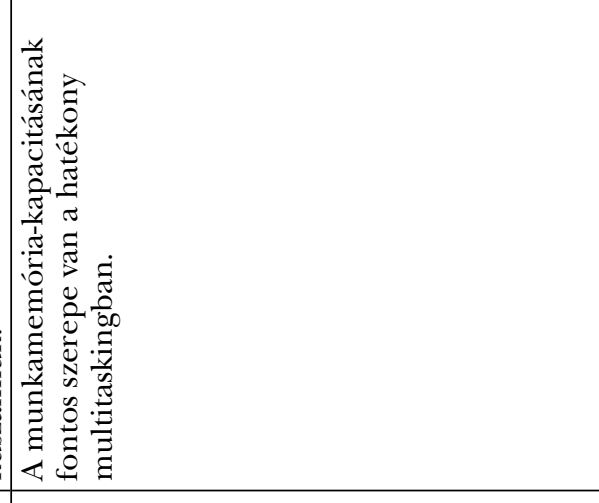 \\
\hline 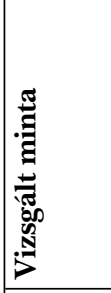 & 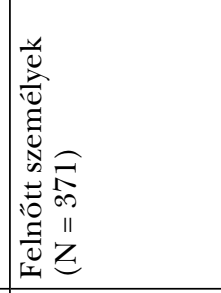 & 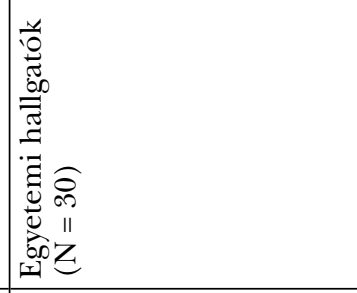 & 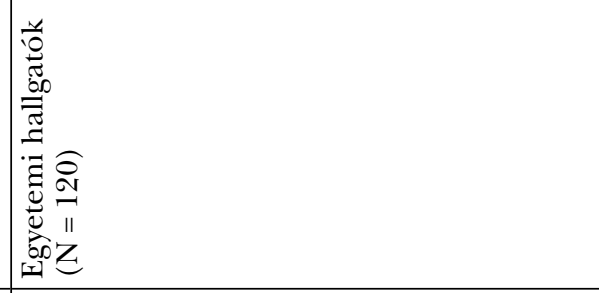 \\
\hline 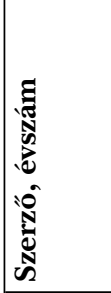 & 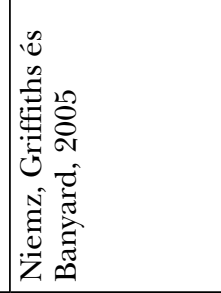 & 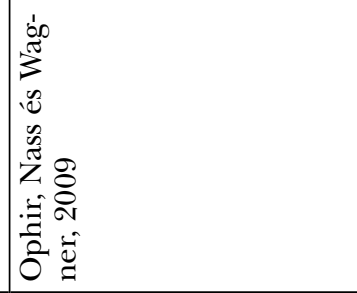 & 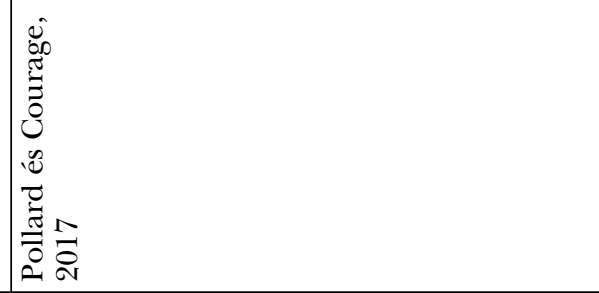 \\
\hline
\end{tabular}




\begin{tabular}{|c|c|c|c|c|c|}
\hline 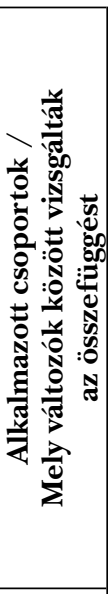 & 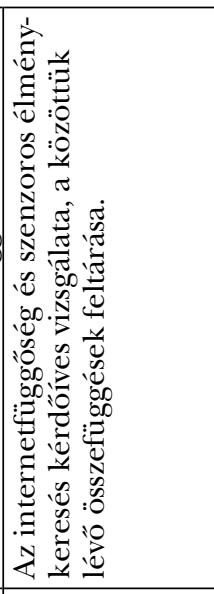 & 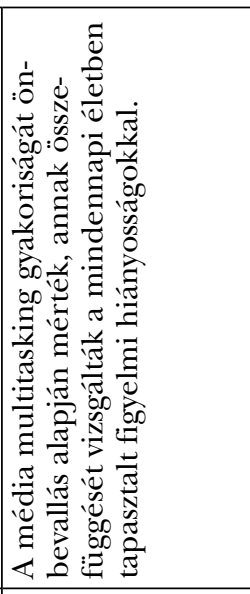 & 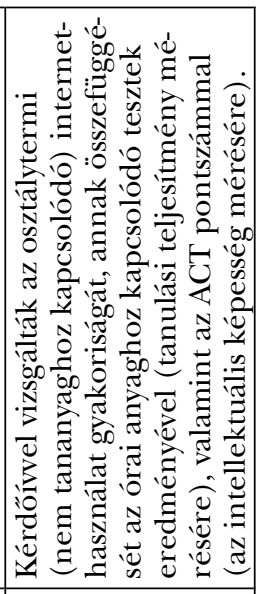 & 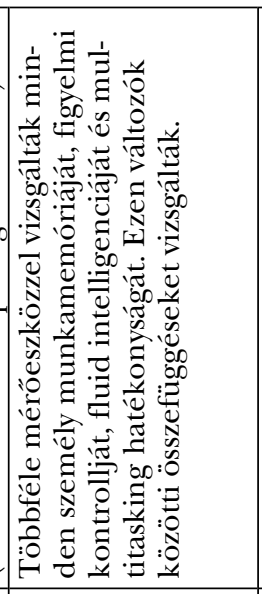 & 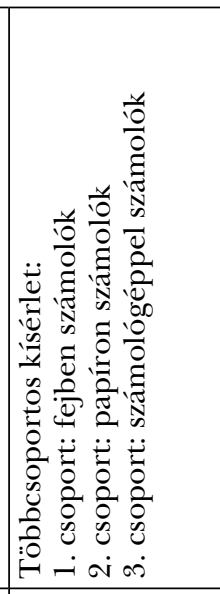 \\
\hline 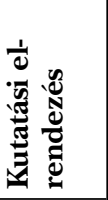 & 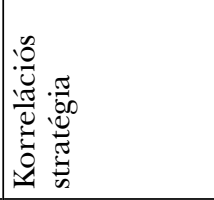 & 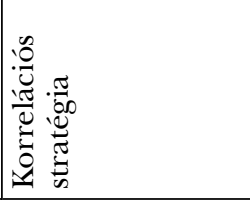 & 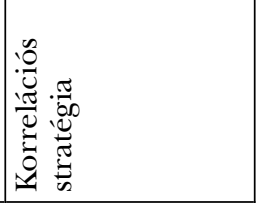 & 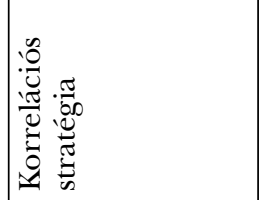 & 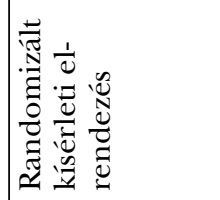 \\
\hline 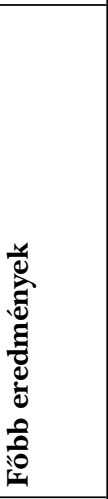 & 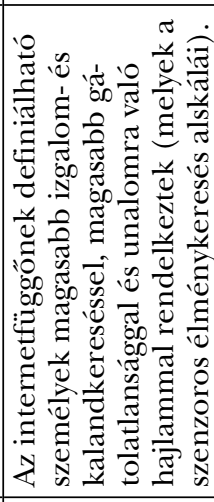 & 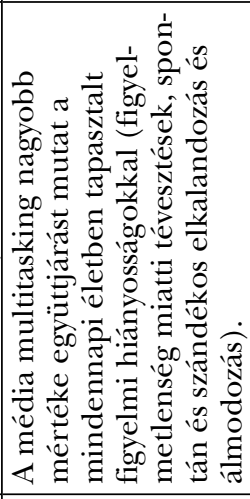 & 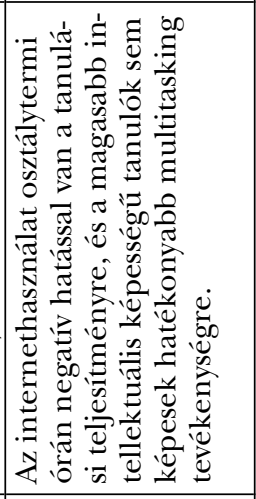 & 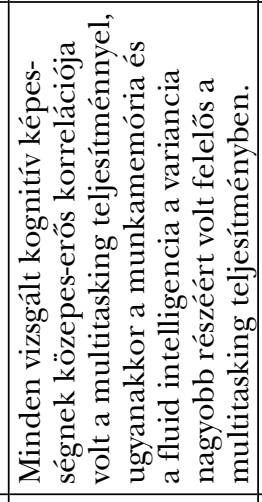 & 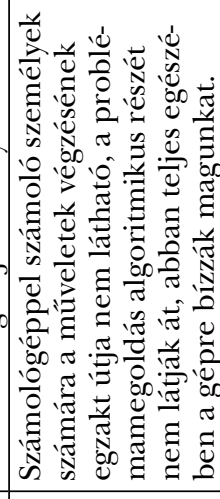 \\
\hline 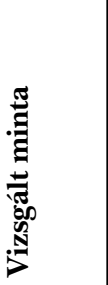 & 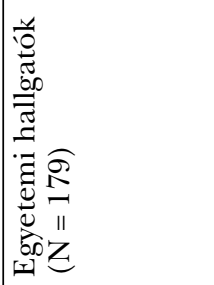 & 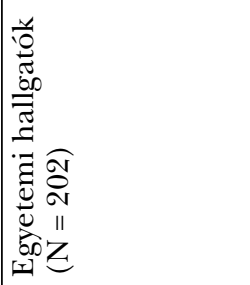 & 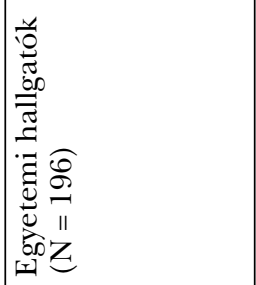 & 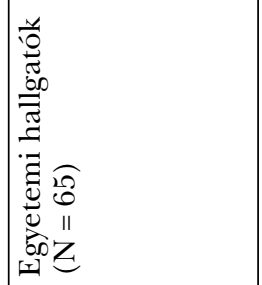 & 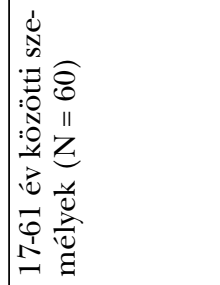 \\
\hline 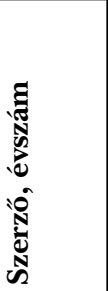 & 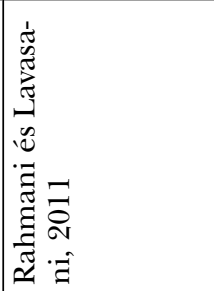 & 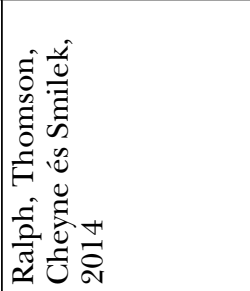 & 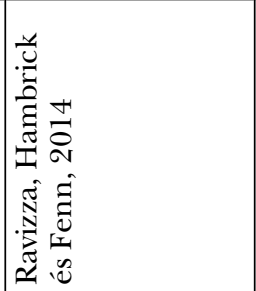 & 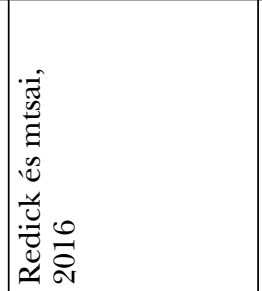 & 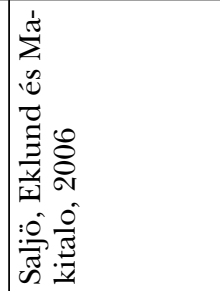 \\
\hline
\end{tabular}




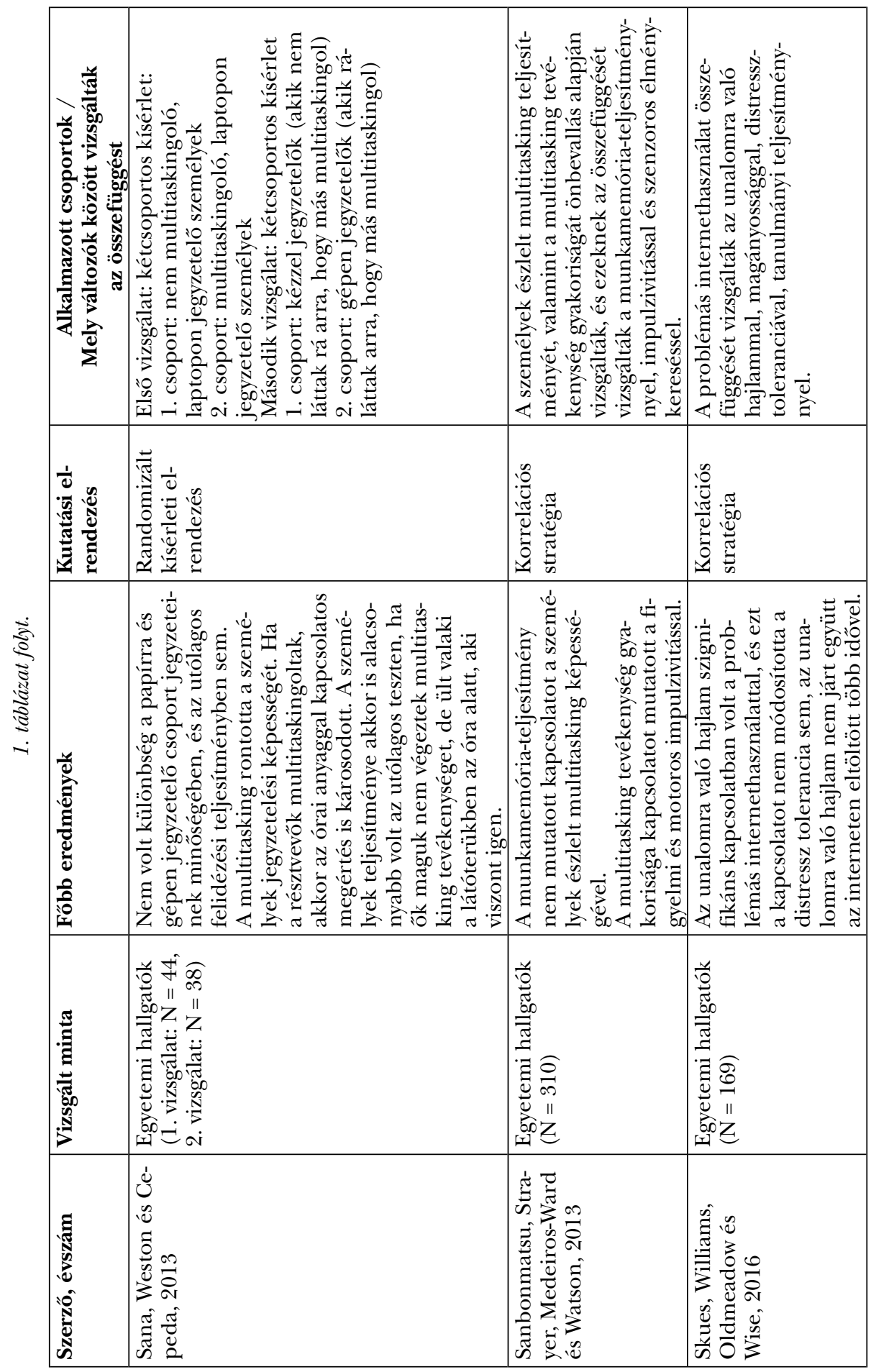









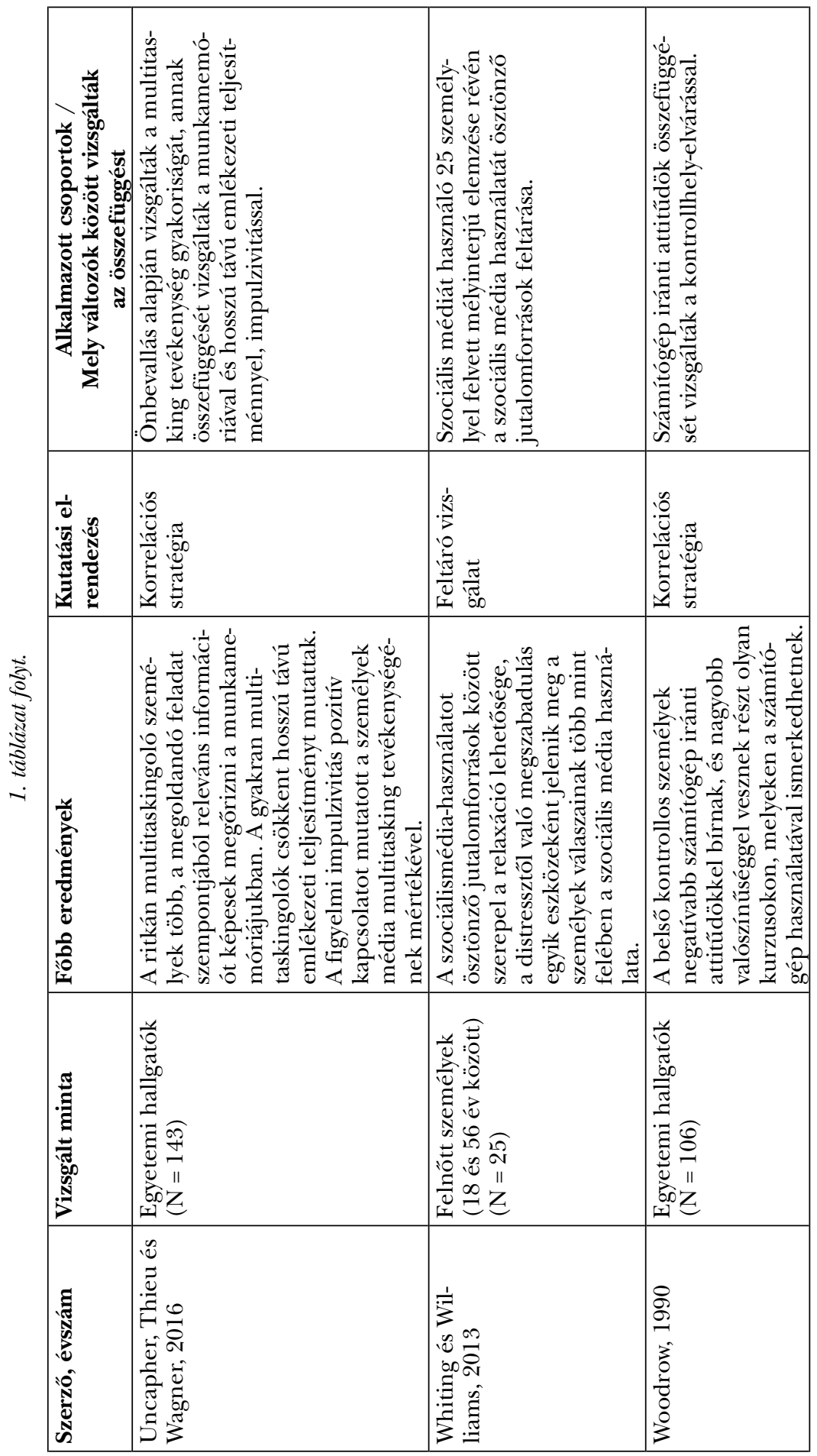


Összességében megállapítható, hogy az IKT-használat kapcsán a megfelelô használati szokások kialakítására, valamint az olyan személyiségvonások elômozdítására szükséges törekedni, melyek lehetôvé teszik a tudatos technológiahasználatot annak érdekében, hogy az IKT-eszközök használatából fakadó negatív hatásokat mérsékeljük. Érdemes lehet a jövôben olyan vizsgálatokat végezni, amelyek a tudatos, kontrollált IKT-használat szempontjából vizsgálják a személyek kognitív múködését és személyiségvonásait, megfeleló kísérleti elrendezést alkalmazva.

Kevés olyan hazai tanulmány van, amely empirikus kutatás eredményeit mutatja be a jelen cikkben megjelenó témákkal kapcsolatban, inkább áttekintésekkel, irodalmi elemzésekkel találkozni a témában (pl. Kovács és Faragó, 2016; Pléh és Faragó, 2016), így hazai színtéren is fontos lenne a megfelelően tervezett empirikus vizsgálatok lefolytatása az IKT-eszközök kognitív múködésre és személyiségtényezôkre gyakorolt hatásával kapcsolatban.

\section{IRODALOM}

Assunçao, R., \& Matos, P. M. (2017). Adolescents' profiles of problematic Facebook use and associations with developmental variables. Computers in Human Behavior, 75, 396-403. https:// doi.org/10.1016/j.chb.2017.05.034

Barr, N., Pennycook, G., Stolz, J. A., \& Fugelsang, J. A. (2015). The brain in your pocket: Evidence that Smartphones are used to supplant thinking. Computers in Human Behavior, 48, 473-480. https://doi.org/10.1016/j.chb.2015.02.029

Billieux, L., Van der Linden, M., \& Rochat, L. (2008). The Role of Impulsivity in Actual and Problematic Use of the Mobile Phone. Applied Cognitive Psychology, 22, 1195-1210. https:// doi.org/10.1002/acp

Błachnio, A., \& Przepiorka, A. (2016). Dysfunction of Self-Regulation and Self-Control in Facebook Addiction. Psychiatric Quarterly, 87(3), 493-500. https://doi.org/10.1007/ s11126-015-9403-1

Cardoso-Leite, P., Kludt, R., Vignola, G., Ma, W. J., Green, C. S., \& Bavelier, D. (2016). Technology consumption and cognitive control: Contrasting action video game experience with media multitasking. Atten Percept Psychophys, 78, 218-241. https://doi.org/10.3758/ s13414-015-0988-0

Chak, K., \& Leung, L. (2004). Shyness and Locus of Control as Predictors of Internet Addiction and Internet Use. Cyberpsychology \& Behavior, 7(5), 559-570.

Contractor, A. A., Weiss, N. H., Tull, M. T., \& Elhai, J. D. (2017). PTSD's relation with problematic smartphone use: Mediating role of impulsivity. Computers in Human Behavior, 75, 177-183. https://doi.org/10.1016/j.chb.2017.05.018

Dávid, M., Dorner, L., Hatvani, A., Soltész, P., Taskó, T., \& Soltész-Várhelyi, K. (2016). Az IKT hatása a kognitív múködésekre iskoláskorban. Magyar Pszichológiai Szemle, 71(1), 165-195.

Dávid, M., Taskó, T., Héjja-Nagy, K., Mester, D., Dorner, L., \& Estefánné Varga, M. (2016). $\mathrm{Az}$ önszabályozó tanulás fejlettségének összefüggései a tanulási eredményességgel és az IKT-használat gyakoriságával. Magyar Pszichológiai Szemle, 71(1/10), 197-225. https://doi. org/10.1556/0016.2016.71.1.10.AZ

Flynn, J. R. (1984). The mean IQ of Americans: massive gains. Psychological Bulletin, 95, 29-51. 
Garcia, L., Nussbaum, M., \& Preiss, D. D. (2011). Is the use of information and communication technology related to performance in working memory tasks? Evidence from seventhgrade students. Computers \& Education, 57(3), 2068-2076. https://doi.org/10.1016/j. compedu.2011.05.009

Goleman, D. (2015). Fókusz. Út a kiválóság felé. Budapest: Libri Kiadó.

Greenfield, P. M. (2009). Technology and Informal Education: What is Taught, What is Learned. Science, 323(5910), 69-71.

Jackson, M. (2008). Distracted: The Erosion of Attention and the Coming Dark Age. New York: Prometheus Books.

Kahneman, D. (2011). Thinking, fast and slow. New York: Farrar, Straus and Giroux.

Kazakova, S., Cauberghe, V., Pandelaere, M., \& De Pelsmacker, P. (2015). Can't See the Forest for the Trees? The Effect of Media Multitasking on Cognitive Processing Style. Media Psychology, 18, 425-450. https://doi.org/10.1080/15213269.2015.1006789

Koo, D. (2009). The moderating role of locus of control on the links between experiential motives and intention to play online games. Computers in Human Behavior, 25(2), 466-474. https://doi.org/10.1016/j.chb.2008.10.010

Kormanik, M. B., \& Rocco, T. S. (2009). Internal Versus External Control of Reinforcement: A Review of the Locus of Control Construct. Human Resource Development Review, 8(4), 463-483. https://doi.org/10.1177/1534484309342080

Kovács, K., \& Faragó, B. (2016). A modern technológia hatása a kognitív képességekre: áttekintés. Magyar Pszichológiai Szemle, 71(1), 127-141.

Kvaszingerné Prantner, C., Soltész, P., Faragó, B., Pléh, C., \& Soltész-Várhelyi, K. (2016). A multitasking jelenség hatása a feladatvégzésre és az idôbeosztásra. Módszertani előtanulmány. Magyar Pszichológiai Szemle, 71(1), 109-125.

Lee, Y., Chang, C., Lin, Y., \& Cheng, Z. (2014). The dark side of smartphone usage: Psychological traits, compulsive behavior and technostress. Computers in Human Behavior, 31, 373-383. https://doi.org/10.1016/j.chb.2013.10.047

Leung, L., \& Zhang, R. (2016). Predicting tablet use: A study of gratifications-sought, leisure boredom, and multitasking. Telematics and Informatics, 33, 331-341. https://doi.org/10.1016/j. tele.2015.08.013

Li, J., Lepp, A., \& Barkley, J. E. (2015). Locus of control and cell phone use: Implications for sleep quality, academic performance, and subjective well-being. Computers in Human Behavior, 52, 450-457. https://doi.org/10.1016/j.chb.2015.06.021

Lin, S. S. J., \& Tsai, C. (2002). Sensation seeking and internet dependence of Taiwanese high school adolescents. Computers in Human Behavior, 18, 411-426.

Loh, K.-K., \& Kanai, R. (2015). How Has the Internet Reshaped Human Cognition? The Neuroscientist, 22(5), 506-520. https://doi.org/10.1177/1073858415595005

Mangen, A., Walgermo, B. R., \& Bronnick, K. (2012). Reading linear texts on paper versus computer screen: Effects on reading comprehension. International Journal of Educational Research, $58,61-68$.

Mayer, K., Lukács, A., \& Pauler, G. (2012) . A 8-tételes Szenzoros Élménykeresés Kérdôív (BSSS-8) magyarországi adaptálása. Mentálhigiéné és Pszichoszomatika, 13(3), 295-310. https://doi. org/10.1556/Mental.13.2012.3.3

Minear, M., Brasher, F., McCurdy, M., Lewis, J., \& Younggren, A. (2013). Working memory, fluid intelligence, and impulsiveness in heavy media multitaskers. Psychon Bull Review, 20, 1274-1281. https://doi.org/10.3758/s13423-013-0456-6

Moisala, M., Salmela, V., Hietajärvi, L., Salo, E., Carlson, S., Salonen, O., et al (2016). Media multitasking is associated with distractibility and increased prefrontal activity in ado- 
lescents and young adults. NeuroImage, 134, 113-121. https://doi.org/10.1016/j.neuroimage.2016.04.011

Mueller, P. A., \& Oppenheimer, D. M. (2014). The Pen is Mightier than the Keyboard: Advantages of Longhand Over Laptop Note Taking. Psychological Science, 25(6), 1159-1168. https:// doi.org/10.1177/0956797614524581

Murphy, K., McLauchlan, S., \& Lee, M. (2017). Is there a link between media-multitasking and the executive functions of filtering and response inhibition? Computers in Human Behavior, 75, 667-677. https://doi.org/10.1016/j.chb.2017.06.001

Newell, L. A. (2015). Redefining Attention (and Revamping the Legal Profession?) for the Digital Generation. Nevada Law Journal, 15(2), 754-825.

Niemz, K., Griffiths, M., \& Banyard, P. (2005). Prevalence of Pathological Internet Use among University Students and Correlations with Self-Esteem, the General Health Questionnaire (GHQ), and Disinhibition. Cyberpsychology \& Behavior, 8(6), 562-570.

Ophir, E., Nass, C., \& Wagner, A. D. (2009). Cognitive control in media multitaskers. PNAS, 106(37), 15583-15587.

Pléh, Cs. (2011). A webvilág kognitív következményei, avagy fényesít, vagy butít-e az internet? Korunk, 22(8), 9-19.

Pléh, Cs., \& Faragó, B. (2016). Az új technológia és a tanulás világa a pszichológus szemével. Magyar Pszichológiai Szemle, 71(1/1), 3-23. https://doi.org/10.1556/0016.2016.71.1.1.AZ

Pollard, M. A., \& Courage, M. L. (2017). Working memory capacity predicts effective multitasking. Computers in Human Behavior, 76, 450-462. https://doi.org/10.1016/j.chb.2017.08.008

Rahmani, S., \& Lavasani, G. M. (2011). The comparison of sensation seeking and five big factors of personality between internet dependents and non-dependents. Procedia - Social and Behavioral Sciences, 15, 1029-1033. https://doi.org/10.1016/j.sbspro.2011.03.234

Ralph, B. C. W., Thomson, D. R., Cheyne, A. J., \& Smilek, D. (2014). Media multitasking and failures of attention in everyday life. Psychological Research, 78, 661-669. https://doi. org/10.1007/s00426-013-0523-7

Ravizza, S. M., Hambrick, D. Z., \& Fenn, K. M. (2014). Non-academic internet use in the classroom is negatively related to classroom learning regardless of intellectual ability. Computers \& Education, 78, 109-114. https://doi.org/10.1016/j.compedu.2014.05.007

Redick, T. S. (2016). On the Relation of Working Memory and Multitasking: Memory Span and Synthetic Work Performance. Journal of Applied Research in Memory and Cognition, 5, 401-409. https://doi.org/10.1016/j.jarmac.2016.05.003

Redick, T. S., Shipstead, Z., Meier, M. E., Montroy, J. J., Hicks, K. L., Unsworth, N., et al (2016). Cognitive Predictors of a Common Multitasking Ability: Contributions From Working Memory, Attention Control, and Fluid Intelligence. Journal of Experimental Psychology: General, 145(11), 1473-1492.

Rothbart, M. K., \& Posner, M. I. (2015). The developing brain in a multitasking world. Developmental Review, 35, 42-63. https://doi.org/10.1016/j.dr.2014.12.006

Rotter, J. B. (1966). Generalized expectancies for internal versus external control of reinforcement. Psychological Monographs: General and Applied, 80(1), 1-28.

Saljö, R., Eklund, A.-C., \& Makitalo, A. (2006). Reasoning with Mental Tools and Physical Artefacts in Everyday Problem-Solving. In V. Verschaffel, F. Dochy, M. Boekaerts, \& S. Vosniadon (Eds), Instructional psychology: Past, present and future trends (pp. 73-91.). Eleseiver Ltd.

Sana, F., Weston, T., \& Cepeda, N. J. (2013). Laptop multitasking hinders classroom learning for both users and nearby peers. Computers \& Education, 62, 24-31. https://doi.org/10.1016/j. compedu.2012.10.003 
Sanbonmatsu, D. M., Strayer, D. L., Medeiros-Ward, N., \& Watson, J. M. (2013). Who Multi-Tasks and Why? Multi-Tasking Ability, Perceived Multi-Tasking Ability, Impulsivity, and Sensation Seeking. PLoS ONE, 8(1), 1-8. https://doi.org/10.1371/journal.pone.0054402

Simons, D. J., Boot, W. R., Charness, N., Gathercole, S. E., Chabris, C. F., Hambrick, D. Z., \& Stine-Morrow, E. A. L. (2016). Do "Brain-Training” Programs Work? Psychological Science in the Public Interest, 17(3), 103-186. https://doi.org/10.1177/1529100616661983

Skues, J., Williams, B., Oldmeadow, J., \& Wise, L. (2016). The Effects of Boredom, Loneliness, and Distress Tolerance on Problem Internet Use Among University Students. International Journal of Mental Health Addiction, 14, 167-180. https://doi.org/10.1007/s11469-015-9568-8

Sparrow, B., Liu, J., \& Wegner, D. M. (2011). Google Effects on Memory: Information at Our Fingertips. Science, 333(6043), 776-778. https://doi.org/10.1126/science.1207745

Sponcil, M., \& Gitimu, P. (2012). Use of social media by college students: Relationship to communication and self-concept. Journal of Technology Research Use, 4, 1-13.

Tangney, J. P., Baumeister, R. F., \& Boone, A. L. (2004). High Self-Control Predicts Good Adjustment, Less Pathology, Better Grades, and Interpersonal Success. Journal of Personality, 72(2), 271-324.

Uncapher, M. R., Thieu, M. K., \& Wagner, A. D. (2016). Media multitasking and memory: Differences in working memory and long-term memory. Psychonomic Bulletin \& Review, 23, 483-490. https://doi.org/10.3758/s13423-015-0907-3

Wallace, P. (2002). Az internet pszichológiája. Budapest: Osiris Kiadó.

Whiting, A., \& Williams, D. (2013). Why people use social media: a uses and gratifications approach. Qualitative Market Research: An International Journal, 16(4), 362-369. https://doi. org/10.1108/QMR-06-2013-0041

Wilmer, H. H., \& Chein, J. M. (2016). Mobile technology habits: patterns of association among device usage, intertemporal preference, impulse control, and reward sensitivity. Psychonomic Bulletin \& Review, 23, 1607-1614. https://doi.org/10.3758/s13423-016-1011-z

Wilmer, H. H., Sherman, L. E., \& Chein, J. M. (2017). Smartphones and Cognition: A Review of Research Exploring the Links between Mobile Technology Habits and Cognitive Functioning. Frontiers in Psychology, 8(605), 1-16. https://doi.org/10.3389/fpsyg.2017.00605

Woodrow, J. E. J. (1990). Locus of Control and Student Teacher Computer Attitudes. Computers \& Education, 14(5), 421-432.

A cikk a Creative Commons Attribution 4.0 International License (https://creativecommons. org/licenses/by/4.0) feltételei szerint publikált Open Access közlemény, melynek szellemében a cikk bármilyen médiumban szabadon felhasználható, megosztható és újraközölhetô, feltéve, hogy az eredeti szerzố és a közlés helye, illetve a CC License linkje és az esetlegesen végrehajtott módosítások feltüntetésre kerülnek. (SID_1) 


\title{
THE RELATIONSHIP BETWEEN ICT-USAGE AND CHANGES IN COGNITIVE FUNCTIONING AND PERSONALITY FACTORS - REVIEW OF INTERNATIONAL EMPIRICAL STUDIES
}

\author{
FARAGÓ, BOGLÁRKA
}

\begin{abstract}
Aim: The goal of this paper is to review the main findings of the international empirical studies which are focusing on the relationship of ICT-usage and cognitive functioning, and on the relationship of ICT-usage and personality factors. In the field of cognitive functioning, this paper studies the followings; reasoning, attention, memory functions, executive functions, intelligence. From the personality traits, this paper engages in impulsivity, sensory seeking and locus of control.

The methodology of the review: This paper reviews the relevant and up-to-date international empirical studies, which are made in the aforementioned fields. Main findings and concluisons: The usage of ICTdevices presumably results in changes in our cognitive functioning, but we can conclude from the results of the reviewed studies, that these changes are the impacts of the maladaptive use of these devices. So probably the most important issue is the acquirement of adequate habits in the filed of ICT-usage to moderate the ICT-devices' negative effects on our cognitive functioning, and to maximize the benefits of these devices. The maladaptive, problematic use of ICT-devices is in relationship with some personality traits, with impulsivity (impatience, low self-control, lack of persistence), with disinhibition, boredom susceptibility, and external locus of control. At the same time the direction of casuality is questionable, so we don't know, if problematic ICT-usage causes these changes in our personality, or conversely; people with these personality traits susceptible more to problematic ICT-usage? If we want to answer this question, we need more randomized controlled studies in this field. Therefore it is important to examine the methodology of the empirical studies which are appeared in this paper, in order to make accurate conclusions about them.
\end{abstract}

Keywords: ICT-usage, cognitive functioning, personality, adaptive ICT-usage, randomized controlled studies 